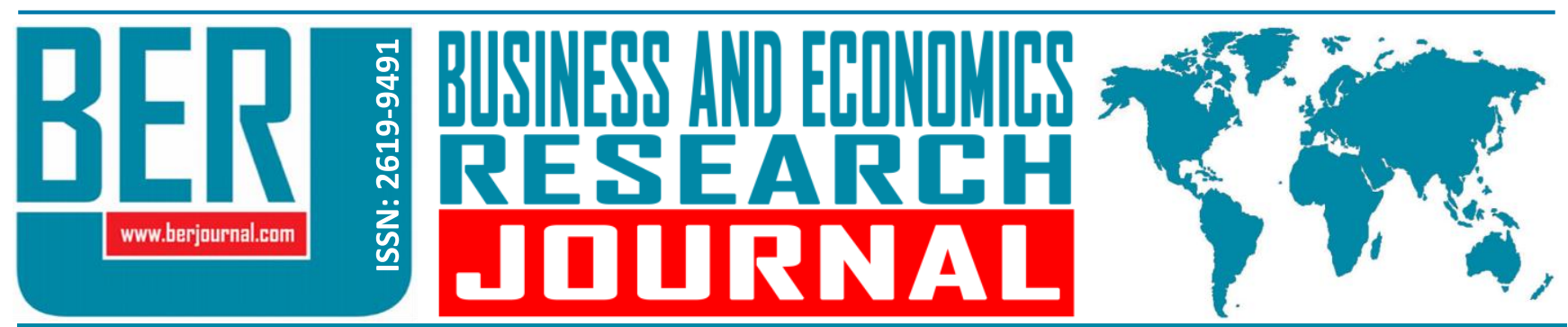

Business and Economics Research Journal Vol. 10, No. 1, 2019, pp. 167-186 doi: 10.20409/berj.2019.161

\section{Lider Üye Etkileşiminin İşe Adanmışlık Üzerindeki Etkisinde Psikolojik Güçlendirmenin Aracı Rolü}

\section{Didem Ozturk Ciftci ${ }^{\mathrm{a}}$}

Öz: Yapılan araştırmada, lider üye etkileşiminin işe adanmışlık üzerindeki etkisi ve psikolojik güçlendirmenin bu etki üzerindeki aracılık rolünün belirlenmesi amaçlanmıştır. Araştırma modeli çerçevesinde oluşturulan hipotezler, tekstil sektöründe çalışmakta olan 186 katılımcıdan anket yöntemi ile elde edilen veri seti ile istatistik analiz programları kullanılarak değerlendirilmiştir. Yapılan analizler sonucunda lider üye etkileşiminin işe adanmışlık ve psikolojik güçlendirme üzerindeki, psikolojik güçlendirmenin de işe adanmışlık üzerindeki etkisini gösteren sonuçlara ulaşılmıştır. Elde edilen bulgular ayrıca, araştırmanın ana hipotezinde de ifade edilen, lider üye etkileşiminin çalışanların işe adanmışlıkları üzerindeki pozitif etkisinde psikolojik güçlendirmenin tam aracılık rolünü doğrular niteliktedir. Araştırma sonuçları ile doğrulanan tam aracılık rolü, lider üye etkileşimi ile oluşan güven duygusunun, liderlerin astlarına yetki devredebilmesine olanak verdiği ve bu yetki devri ile psikolojik açıdan güçlenen çalışanların ise işe adanmışlıklarının arttığı şeklinde yorumlanabilir. Araştırmanın tartışma ve sonuç bölümünde, elde edilen bulgular yazın ile karșılaştırılarak yorumlanmıştır.

\section{The Mediating Role of Psychological Empowerment in the Effect of Leader-Member Exchange on Work Engagement}

\begin{abstract}
In this research, it is aimed to determine the effect of leader-member exchange on work engagement and the mediating role of psychological empowerment on this effect. The hypotheses formed within the framework of the research model were evaluated by using the data set from 186 participants working in textile sector and the statistical analysis programs. As a result of statistical analysis, the research findings showed that the effect of the leader-member exchange on work engagement and psychological empowerment and finally psychological empowerment on work engagement. The result of the study also confirm the fully mediating role of psychological empowerment in the positive impact of leader-member exchange on employees' work engagement, expressed in the main hypothesis of the study. It can be interpreted that the fully mediating role, verified by the research results, allows leaders to delegate authority to their subordinates with the sense of confidence created by the leader-member exchange and increase the engagement of psychologically empowered employees with this authority transfer. In the discussion and conclusion part of the study, the obtained results were compared with the literature.
\end{abstract}

Anahtar Sözcükler: LiderÜye Etkileşimi, İşe Adanmışlık, Psikolojik Güçlendirme, Aracılık Etkisi

JEL: D23, j24, M54

$\begin{array}{ll}\text { Geliş } & : 10 \text { Ekim } 2018 \\ \begin{array}{l}\text { Düzeltme } \\ \text { Kabul }\end{array} & : 21 \text { Kasım } 2018 \\ & : 11 \text { Aralık } 2018 \\ \text { Tür } & : \text { Araştırma }\end{array}$

Keywords: Leader-Member Exchange, Work Engagement, Psychological Empowerment, Mediation Effect

JEL: D23, j24, M54

$\begin{array}{ll}\text { Received } & : \text { 10 October } 2018 \\ \text { Revised } & : 21 \text { November } 2018 \\ \text { Accepted } & : \text { 11 December } 2018 \\ \text { Type } & : \text { Research }\end{array}$
and Economics Research Journal, 10(1), 167-186.

The current issue and archive of this Journal is available at: www.berjournal.com 


\section{Giriş}

Çalışanların işe adanmışlığı, özellikle örgütsel davranış alanında pozitif yaklaşımların kendini göstermeye başladığı son yıllarda işletmelerin ve araştırmacıların ilgisini çeken bir konu olmuştur. İnsan kaynağının eşsizliği ve rekabet gücünü oluşturan unsurlar arasındaki stratejik değeri, bu kaynağın en verimli şekilde nasıl değerlendirilebileceğine ilişkin araştırmalara hız kazandırmıştır. Yapılan araştırmalar işe adanmışlığın sadece çalışan tutum ve davranışları ile örgütsel sonuçlar üzerindeki olumlu etkilerini değil (Sonnentag, Mojza, Binnewies ve Scholl, 2008; Harter vd., 2002) aynı zamanda işe adanmış çalışanların diğer çalışanlara göre daha enerjik olduğunu, iş-yaşam dengesini kurabildiğini, işletme amaçlarına ulaşmada gönüllü ekstra çaba gösterdiğini de ortaya koymaktadır (Salanova ve Schaufeli, 2008; Schaufeli ve Bakker, 2010; Gutermann vd., 2017). Buradan yola çıkarak, çalışanların işe adanmışlıklarını etkileyen unsurların belirlenmesi ve söz konusu unsurların birbirleri ile olan ilişkilerinin tespit edilmesinin, işletmelerin örgütsel çıktılarının geliştirilebilmesi açısından olumlu katkı sağlayacağı söylenebilir.

Lider üye etkileşimi teorisini diğer liderlik teorilerinden ayıran temel niteliklerinden birisi liderin bazı üyeler ile daha yakın ve niteliği yüksek, bazı üyelerle ise daha mesafeli, düşük nitelikte ve otoriteye dayalı ilişkiler geliştirebileceği düşüncesidir (Gündüz Çekmecelioğlu ve Ülker, 2014). Yapılan araştırmaların lider üye etkileşiminin, çalışan tutum ve davranışları üzerindeki etkisini doğruladığı da dikkate alınarak (Gündüz Çekmecelioğlu ve Ülker, 2014; Bulgurcu Gürel 2016; Guterman vd., 2017) söz konusu etkileşimin işe adanmışlık ile olan ilişkisi ve bu ilişkide psikolojik güçlendirmenin aracı değişken olduğu varsayımı araştırma konusu olarak belirlenmiştir.

Yapılan yazın taramasında araştırma değişkenlerinin birbirleri ile ikili ilişkilerini ortaya koyan çalışmalar olmasına rağmen (Jose ve Mampilly, 2014; Breevaart vd., 2015; Schermuly ve Meyer, 2016; Radstaak ve Hennes, 2017), lider üye etkileşimi ve işe adanmışlık ilişkisinde psikolojik güçlendirmenin aracı değişken olarak yer aldığı bir çalışmanın olmadığı tespit edilmiştir. Bu bağlamda, elde edilen sonuçların akademik yazına katkı sağlaması amaçlanmaktadır. Araştırma, Ordu ilinde faaliyet gösteren tekstil işletmeleri çalışanları ile gerçekleştirilmiştir. Sektör, yapısı itibariyle işgücüne dayalı olduğundan üretim kalitesi ve performans açısından çalışanların işleri ile ilgili duygu ve tutumlarının önem taşıdığı ifade edilebilir (Erdil vd., 2004; 25; Bağcı, 2013: 179).

Araştırmada ilk olarak değişkenlere ilişkin kavramsal çerçeve ve değişkenlerin birbirleri ile olan ilişkileri bağlamında araştırma hipotezlerinin kuramsal temelleri oluşturulmuştur. Sonraki bölümde araştırma yöntemi açıklanmış ve oluşturulan hipotezler belirlenen yöntemlerle sınanmıştır. Son bölümde ise, araştırma sonuçları ile bu sonuçların değerlendirilmesi yer almaktadır.

\section{Kavramsal Çerçeve}

\subsection{Lider Üye Etkileşimi}

Lider ve üye arasındaki sosyal etkileşimi dikkate alan bir yaklaşım olarak lider üye etkileşimi kuramı temelde, görevlerin yerine getirilmesinde lider ile çalışan arasında çift taraflı bir alışveriş ilişkisinin var olduğunu (Wayne ve Green, 1993: 1432) ve bunun gerek üyelerin gerekse liderin davranış biçimindeki değişiklikler üzerinde etkili olduğunu ileri sürmektedir. Lider-üye etkileşimi kuramı, liderlerin bazı astlarıyla olan yüksek kaliteli sosyo-duygusal ilişkilerden, diğerleriyle olan düşük-kaliteli işlemsel ilişkilere kadar değişen farklılaşmış ilişkiler geliştirdiğini öne sürmektedir (Matta vd., 2015: 1686). Bir başka ifadeyle, liderin üyelerinin her birine farklı davranış biçimleri ile yaklaştığı, onlarla ayrı ayrı ilişkiler geliştirdiği ve her astıyla birebir etkileşim içerisinde olduğu öngörülmektedir (Graen ve Schiemann, 1978: 211; Dunegan, Duchon ve Uhl-Bien, 1992: 59-60) . Lider üye etkileşimi kuramına göre, liderlik yalnızca liderin üyeleri değil, üyelerin de lideri etkilediği çift taraflı bir süreçtir (Graen ve Uhl-Bien, 1991: 29). Kuramın lider üye ilişkisine bu çift yönlü yaklaşımı, daha önce geliştirilen ve liderden izleyicilere yönelen etkiyi temel alan diğer liderlik modellerinden farklılaştığı noktayı da ifade etmektedir.

Kuramın ortaya çıkışı ve evreleri incelendiğinde gelişimin dört temel aşamadan oluştuğu görülmektedir. İlk evreyi, diğer bir ifadeyle kuramın başlangıç noktasını "Dikey íkili Bağlantı" yaklaşımı 
oluşturmaktadır. Dansereau, Cashman ve Graen (1973) tarafından geliştirilmiş olan dikey ikili bağlantı yaklaşımının, lider üye etkileşimi kuramının günümüzdeki kavramsal yapısına ulaşmasını sağlayan temelleri atmış olduğu söylenebilir. Yazarlar, bu kuramda adı geçen ikili bağlantı kavramının, bir lider ile izleyiciyi ya da bir yönetici ile çalışanı ifade ettiğini belirtmektedir. Bu evrede, ikili gruplar "grup içi" (in group) ve "grup dışı" (out group) şeklinde tanımlanmıştır. Lideri ile yüksek etkileşime sahip olan ast, liderin gözünde "grup içi" bir üye olarak; buna karşılık lideri ile daha düşük düzeyde bir etkileşim ilişkiye sahip astlar ise "grup dışı" olarak nitelendirilmektedir (Özutku, Ağca ve Cevrioğlu, 2008: 194). Kuramın ikinci evresinde lider üye etkileşiminin karakteristik özelliklerinin ve örgütsel etkilerinin araştııılmasına, üçüncü aşamada ise ikili ilişkilerin yapısının tanımlanmasına odaklanılmıştır. Dördüncü ve son gelişim aşamasında ise, lider üye etkileşiminin dikey ikili ilişkilerden birden fazla ilişki ağını içeren grup ve örgütsel düzeydeki etkileşimlerin analiz edilmesi sürecine evrildiği görülebilir (Graen ve Uhl-Bien, 1995: 225). Söz konusu gelişim sürecinin aşamaları kuramın liderlik modeli olarak ne sunduğunun yanı sıra araştırmaların analiz düzeylerindeki değişimi de göstermektedir.

Lider üye etkileşimi kuramı yazında "Rol Teorisi" ve "Sosyal Mübadele Kuramı"na dayandırılmaktadır. Kahn vd. (1964) tarafından ortaya atılmış olan rol teorisi, sosyal davranış biçimlerinin, bireyin içinde bulunduğu sosyal sistemin koşullarına, bireyin bu sosyal sistemde üstlenmiş olduğu rollere, rol beklentilerine ve referans gruplarına göre şekillendiğini ifade etmektedir. Katz ve Kahn (1978) örgütsel açıdan bu yaklaşımı, çalışanların örgüt içinde lider tarafından ya da örgütsel süreçler ile belirlenmiş rolleri üstlendiği ve bu rollerden kaynaklanan beklentileri yerine getirdiği şeklinde açıklamıştır. Liderler ise çalışanları verilen bu rolleri ve beklentileri yerine getirme çabalarına göre değerlendirerek karşılığında sağlanacak kaynakları belirlemektedir (Dansereau vd., 1975). Bu teori bağlamında, lider ile çalışan arasındaki etkileşimin şekillenmesinde rollerin yerine getiriliş biçimi ve derecesinin etkili olduğu söylenebilir.

Lider üye etkileşimi kavramının dayandığı diğer kuram olan ve Blau (1964) tarafından ortaya atılan sosyal mübadele kuramı ise, pozitif eylemlerin alıcısı konumunda olanların kendilerini eylemi gerçekleştiren tarafa karşı borçlu hissettikleri varsayımına dayanmaktadır. Kurama göre alıcı konumunda yer alan kişi pozitif eylemi gerçekleştiren kişiye eşdeğer bir geri bildirimde bulunduğunda borçluluk hissi azalmaktadır (Bernerth vd., 2007: 980). Kuram lider üye etkileşimi açısından değerlendirildiğinde, çalışanların örgüte katkı sağlama noktasındaki çaba ve girişimlerinin liderler tarafından sosyal destek ya da finansal teşvik gibi kaynaklarla karşılık bulduğu ifade edilebilir (Walker, 2011: 4). Sosyal mübadele kuramındaki söz konusu karşılıklı etkileşim, lider üye etkileşimi kuramında belirtilen ve kuramı diğer liderlik yaklaşımlarından farklı kılan, hem liderden izleyiciye, hem de izleyiciden lidere doğru çift yönlü ilişkiler bakış açısı ile örtüşmektedir.

Lider üye etkileşimi, Liden ve Maslyn (1998) tarafından "etki, katkı, vefakârlık ve saygı" olmak üzere dört boyuttan oluşan bir yapı şeklinde değerlendirilmiştir. Oluşturulan bu yapıda etki, etkileşimin gerçekleştiği taraflar arasında, iş ya da profesyonel değerlerden daha çok, kişilerarası çekiciliğe dayanan karşııklı ilişki olarak tanımlanmıştır. Burada bahsi geçen etki faktörü, duygusal etkiyi, bir başka ifade ile lider ve izleyicinin iş dışında kişisel olarak karşıııkı besledikleri saygı ve sevgiyi ifade etmektedir (Akkaya, 2015: 36). Dienesch ve Liden (1986) katkı faktörünü, tarafların ortak amaçları gerçekleştirmek üzere ortaya koydukları işin miktar ve kalitesi olarak, vefakârlık faktörünü ise birbirlerine karşı olan sadakat ve desteği olarak tanımlamaktadır. Oluşturulan modelde yer alan profesyonel saygı faktörü ise yazarlar tarafından lider ve izleyicinin örgüt içinde ya da dışında sahip olduğu saygınlık düzeyi ve algılanış biçimi olarak ifade edilmektedir.

\section{2. İşe Adanmışlık}

İşe adanmışlık kavramı, pozitif örgütsel davranış yaklaşımından doğmuş ve yazında ilk kez Kahn tarafından psikolojik bir durum olarak ele alınmıştır. Kahn (1990: 694), işe adanmışlığı "çalışanların kendilerini fiziksel, duygusal ve bilişsel olarak tam anlamıyla işlerine vermesi" şeklinde ifade etmiştir. Tanımda belirtilen fiziksel adanmışlık çalışanın sahip olduğu fiziksel enerjinin büyük bölümünü kendi isteği ile işine aktardığı halde kendini tükenmiş hissetmeyişi; duygusal adanmışlık, işini ilham, şevk ve gurur gibi olumlu duygularla yapması, zihinsel adanmışık ise diğer tüm şeyleri unutacak düzeyde zihnini işine odaklaması anlamına gelmektedir (Babcock-Roberson ve Strickland, 2010: 316). Kahn (1990), yapmış olduğu tanımlamanın yanında işe adanmışlığın "anlamlılık, güven ve uygunluk" koşullarında gerçekleşebileceğini de ifade etmektedir. Bir başka ifadeyle, işe adanmışlığın gerçekleşebilmesi için çalışanın işinde diğer çalışanlardan farklı bir amaç ve 
anlam bulabilmesi, kendini olduğu biçimde ifade ettiğinde bu durumdan olumsuz etkilenmeyeceğini bilmesi ve işini yapmak için gerekli fiziksel, duygusal ve zihinsel tüm kaynaklara sahip olduğuna inanması gerekmektedir (Kahn, 1990:714; May, Gilson ve Harter, 2004: 15).

İse adanmışlık, araştırmacılar tarafından iki şekilde değerlendirilmektedir. Bunlardan ilki, kavramı tükenmişlik kavramının tam zıttı olarak ele almakta, diğer yaklaşım ise tükenmişlik ve işe adanmışlığı birbirinden bağımsız ancak birbiriyle ters yönlü ilişkisi olan kavramlar olarak değerlendirmektedir (Schaufeli ve Bakker, 2004: 308). Her iki açıdan da bakıldığında işe adanmışlı̆̆ın, pozitif psikoloji akımını örgütsel yansıması olan pozitif örgütsel davranış yaklaşımından doğmuş olduğu doğrulanmaktadır. İşe adanmışlık kavramı psikolojik olarak değerlendirilerek yapılan tanımlar dışında davranışsal yönü ile de tanımlanmıştır. Örneğin işe adanmışlığı, Macey ve Schneider (2008: 6), çalışma yaşamında isteğe bağı gönüllü ve fazladan gösterilen çaba ile karakterize olmuş bir davranış biçimi şeklinde açıklarken, Tasker (2004; Aktaran: Robertson Smith ve Markwick, 2009: 11) ise, çalışanların yapabildiklerinin en fazlasını yaptıkları karşılıklı fayda barındıran bir ilişki biçimi olarak tanımlamaktadır. Bu bağlamda, işe adanmış çalışanın; enerjik, öngörücü, insiyatif alan ve tutkuyla çalışarak kendisinden beklenenin üzerinde performans sergileyen çalışan olduğu söylenebilir (Bakker, Albrecht ve Leiter, 2011: 5). Ayrıca işe adanmış çalışanlar, iş koliklerden farklı olarak karşı koyamadıkları içü̈düsel bir dürtü ile değil, işlerini eğlenceli buldukları ve çalışırken keyif aldıkları için çok çalışırlar (Gorgievski, Bakker ve Schaufeli, 2010: 85). Tüm bu sayılan özelliklere bağlı olarak, sahip olduğu insan kaynağının ne kadar eşsiz ve önemli olduğunu farkına varan işletmeler, bu insan kaynağının işe adanmış çalışanlardan oluşmasını da önemsemektedir.

Işe adanmışık kavramı, bu konuda birçok çalışma yapmış olan Schaufeli tarafından üç boyuttan oluşan bir model ekseninde tanımlanmıştır. Schaufeli vd. (2001: 74)'e göre işe adanmışlık; işle ilgili pozitif, tatmin edici duygular içeren, ayrıca dinçlik, kendini adama ve yoğunlaşma ile karakterize olduğu düşünülen duygusal ve bilişsel bir durumdur. Bu yapıda dinçlik, bireyin çalışma esnasında yüksek düzeyde enerji ve zihinsel istek taşıması ve bu isteği karşılaştığı tüm zorluklar karşısında muhafaza etmesi; kendini adama, bireyin işine derinden bağlanarak, yaptığı iş hakkında heyecan, gurur ve ilham hisleri taşıması; yoğunlaşma ise, bireyin işine tümüyle konsantre olarak, çalışması ve zamanın nasıl geçtiğini fark etmemesi şeklinde tanımlanmaktadır (Schaufeli vd., 2002: 74).

\subsection{Psikolojik Güçlendirme}

İş yaşamı ve örgütsel davranış yazınında 1980'li yıllarda ifade edilmeye başlanan ve gerek yönetsel faaliyetlerde uygulanabilirliği gerekse performans üzerindeki etkisi nedeniyle yoğun ilgi gören (Aslam, 2017: 12) güçlendirme kavramı, çalışanların kendi kararlarını almalarına ve kendi eylemlerinin sorumluluğunu üstlenmelerine imkân sağlayan örgütsel ortamın oluşturulmasını ifade eden bir olgu olarak tanımlanmaktadır (Pastor, 1996: 5; Erstad, 1997:325). Psikolojik güçlendirme ise, çalışanların güçlendirilebilmesinin psikolojik olarak desteklenmeleri ile mümkün olacağı temeline dayanan bir yaklaşımdır (Şan, 2017: 11). Conger ve Kanungo (1988), psikolojik güçlendirmeyi, pozitif psikolojik sermaye kavramının boyutlarından birisi olan ve kişinin verilen görevleri tamamlama, istenilen sonuçlara ulaşma konusunda kendisine ve yeteneklerine olan inancı (Bandura, 1994: 71) olarak ifade edilen "Öz yeterlilik" temelinde açıklamışlardır. Bir başka ifadeyle yazarlar, psikolojik güçlendirmeyi çalışanların öz yeterlilik algılarııın desteklenmesi veya yetersizlik algısının ortadan kaldırılması şeklinde değerlendirmektedir. Psikolojik güçlendirme kavramına ilişkin diğer bir yaklaşım ise Thomas ve Velthouse (1990) tarafından geliştirilen bilişsel yaklaşımdır. Bu yaklaşımda psikolojik güçlendirme, kişinin güçlendirilmiş hissetme konusundaki algısına ilişkin bilişsel düzeyinde bir farklılaşma olması durumu olarak tanımlanmaktadır (Kesen, 2015: 6532). Yazarlar ayrıca psikolojik güçlendirmenin çok boyutlu bir kavram olduğunu bu nedenle tek yönlü değerlendirilemeyeceğini ileri sürmüşler ve buna bağı olarak kavrama ilişkin; anlam, yetkinlik, seçim ve etki olgularından oluşan dört boyutlu bir yapı önermişlerdir. Spreitzer (1995) ise Thomas ve Velthouse (1990) tarafından oluşturulan dört boyutu, anlam, yeterlilik, özerklik ve etki olmak üzere güncellemiş ve bu şekilde bir ölçme aracı geliştirmiştir. Bu yapıda yer alan anlam; bireyin işe ilişkin amaç ve hedefleri ile bireysel ideal ve standartları arasındaki ilişkiyi; yeterlilik, belirlenen amaçlara ulaşma konusunda yeteneklerine olan inancını; özerklik, eylemleri başlatma ve düzenleme konusunda seçim yapma şansına ya da özerkliğe sahip olduğu konusundaki algısını; etki ise, yönetimsel ya da 
stratejik süreçlerin sonuçlarını etkileyebilme derecesini ifade etmektedir (Thomas ve Velthouse, 1990: 666; Spreitzer, 1995:1443). Tanımlanan dört boyutun bütünleşik etkisi söz konusu olduğunda, bir başka ifadeyle bireyin işine yönelik anlam, yetkinlik, seçim ve etki unsurlarına ilişkin algısı psikolojik güçlendirme üst boyutunu oluşturduğunda, bireyde psikolojik olarak göreve yönelik motivasyon oluşmaktadır.

Psikolojik güçlendirmenin temelinde, yönetimin çalışanları psikolojik açıdan güçlendirmek için yapmış olduklarından ziyade, yapılanların çalışanlar tarafından nasıl algılandığı yer almaktadır (Conger ve Kanungo, 1988:474; Thomas ve Velthouse 1990). Bir başka ifadeyle psikolojik güçlendirmeyi gerçekleştirmek için üst yönetim tarafından yapılan faaliyetler, çalışanlar tarafından kendilerini güçlendiren uygulamalar olarak algılanmadıkça istenilen sonuca ulaşılamayacaktır (Çöl, 2004: 8).

\section{Değişkenler Arasındaki ilişsiler ve Hipotezlerin Oluşturulması}

\subsection{Lider Üye Etkileşimi ve İşe Adanmışlık ilişkisi}

Yapılan araştırmalar, işlerine adanmış çalışanların ortalama standartlarda çalışanlara göre daha yüksek performans gösterdiklerini ve ekstra rol davranışları sergilemeye daha yatkın olduklarını göstermektedir (Bakker ve Demerouti, 2008; Bal ve De Lange, 2015; Sekhar vd., 2018). Bu bağlamda işletmeler açısından işlerine adanmış çalışanları bulma, seçme ve elde tutmanın önemi kadar, adanmışlığı etkileyen faktörlerin belirlenmesinin de gerekliliğinden söz edilebilir. Bu faktörlerden birinin de lider üye etkileşimi olduğunu gösteren araştırmalar mevcuttur (Radstaak ve Hennes, 2017: 6; Maus, 2018: 120). Ayrıca, Meng ve Wu (2015: 54), Çin'de öğretmenler ile gerçekleştirdikleri çalışmalarında Saks (2006) tarafından oluşturulan ve yönetici desteğinin işe adanmışlığın öncülü olduğu modele dayandırarak lider üye etkileşiminin işe adanmışlığı olumlu etkilediğini öne sürmüşlerdir. Araştırma sonucu elde ettikleri bulgular da yazarların oluşturduğu bu hipotezi doğrular niteliktedir.

Lider üye etkileşimi ile işe adanmışıı arasındaki ilişki, sosyal mübadele kuramı ile açıklanabilir. Sosyal mübadele kuramı, örgütsel anlamda ilişkileri karşılıklıık çerçevesinde açıklamaya çalışmaktadır. Örgüt tarafından çalışanlara sağlanan kaynakların, çalışanlar açısından olumlu ve yeterli olarak algılanması ve bunun karşılığında çalışanların örgüt adına kendilerine biçilen rolleri üstlenmeleri ve verilen sorumlulukları yerine getirmeleri çalışan ile örgüt arasında meydana gelen mübadele ilişkisini ifade etmektedir (Bedük ve Ertürk, 2015: 5). Lider üye etkileşimi ekseninde değerlendirildiğinde, liderin yüksek kaliteli etkileşim içinde olduğu çalışan, bu davranış biçimini olumlu bir girdi olarak değerlendirmekte, bu ilişkiye değer vermekte (Breevaart vd., 2015: 757) ve bunun sonucu olarak işi ile ilgili pozitif duygular geliştirebilmektedir. İ̧i ile ilgili olarak olumlu duygulara sahip olan çalışanın ise tüm fiziksel ve zihinsel enerjisini gönüllü olarak işine vermesinin kolaylaşması, bir başka ifadeyle lider üye etkileşiminin, çalışanın işe adanmışı̆̆ını olumlu etkilemesi beklenebilir.

Bu bilgiler ışığında araştırmanın bir numaralı hipotezi şu şekilde oluşturulmuştur:

H1: Lider üye etkileşimi, çalışanların işe adanmışlık düzeylerini pozitif yönlü ve anlamlı olarak etkilemektedir.

\subsection{Lider Üye Etkileşimi ve Psikolojik Güçlendirme ilişkisi}

Lider üye etkileşimi kuramı, liderlerin bazı çalışanları ile diğerlerinden daha yüksek kalitede, resmi iş ilişkisinin ötesine geçen ve değer verdikleri ilişkiler kurduğunu ileri sürmektedir. Söz konusu yüksek kaliteli ilişkiler, daha yüksek seviyede güven, dikkat, iletişim, ödül, özel ayrıcalıklar ve yönetici desteği gibi olumlu örgütsel kaynakları da beraberinde getirmektedir (Hill, Kang ve Seo, 2014: 774). Araştırmalar, liderlerin astlarını güçlendirmelerinin onlara güvenmeleri ile mümkün olduğunu (Durmaz, 2012: 59), buna bağlı olarak da lider üye etkileşiminin sağlamış olduğu güven ile katııımı ve destekleyici yaklaşımın çalışanların psikolojik güçlendirme algısını olumlu etkilediğini göstermektedir (Kim ve George 2005: 471; Schermuly ve Meyer, 2016: 675). Conger ve Kanungo (1988), Spreitzer (1997) ile Thomas ve Velthose (1990) gibi psikolojik güçlendirme konusunda önde gelen araştırmacılar, liderlik tarzları, ödül sistemleri, iş tasarımı gibi faktörleri, güçlendirmeyi etkileyen başlıca unsurlar olarak ifade etmektedir. 
Psikolojik güçlendirme, liderin gücünü astları ile paylaşması olarak da değerlendirilmektedir (Conger ve Kanungo, 1988). Liderin izleyiciye olan güveni, izleyicinin karar alma mekanizmalarına katılımını kolaylaştırmakta, bu da çalışanların öz yeterlilik duygusunu arttırmaktadır (Hill, Kang ve Seo, 2014: 774). Bu açıdan, lider ile astları arasında gerçekleşen yüksek düzeyde, kaliteli etkileşimin oluşturduğu güven ortamının, liderin astlarını psikolojik olarak güçlendirmeye yönelik paylaşımcı tavrını ve astın da bu tavrı algılayışını olumlu şekilde etkilemesi beklenebilir.

Yukarıdaki bilgiler bağlamında araştırmanın iki numaralı hipotezi şu şekilde oluşturulmuştur:

H2: Lider üye etkileşimi, psikolojik güçlendirmeyi pozitif yönlü ve anlamlı olarak etkilemektedir.

\subsection{Psikolojik Güçlendirme ve İşe Adanmışılı illişkisi}

Yapılan araştırmalar, çalışanların psikolojik olarak güçlendirilmesinin; ihtiyaçlarının, değer yönelimlerinin, güvenin, öz yeterliliğinin artması noktasında olumlu bir etki oluşturarak duygu, düşünce, algı ve davranışlarında cesaret verici bir dönüşüme neden olduğunu göstermektedir (Conger ve Kanungo 1988: 474; Mahmood ve Sahar, 2017: 1088). Ayrıca, çalışanlar psikolojik olarak güçlendirildiklerinde işleri ile ilgili bir takım kararlarda özerk olabildikleri ve bu kararların sorumluluğunu ve risklerini üstelendikleri için daha fazla sorumluluk ve kontrol duygusu hissetmekte, bunun sonucu olarak da işlerini daha anlamlı bulmaktadırlar (Salazar vd., 2006: 5). Kahn (1990) tarafından geliştirilen modelde, işe adanmışlığın gerçekleşmesi için üç temel koşuldan bahsedilmektedir. Bu koşullar; güven, anlamlılık ve uygunluktur. Burada bahsi geçen güven, bireyin iş yaşamına ya da imajına zarar verilebileceği endişesi taşımadan kişiliğini göstererek çalışabilmesi durumu; uygunluk bireyin kendini işine odaklaması için gerekli tüm kaynaklara sahip olduğuna iliş̧in inancı olarak tanımlanabilir (Kahn, 1990). Anlamlıık kavramı ise, çalışanın işi ile ilgili olarak çevre tarafından algılanan ve görülenden çok daha farklı bir amaç bulabilmesidir. Çalışanın psikolojik güçlendirme sayesinde işi ile ilgili anlam duygusunun artmasının, işe adanmışlık koşullarından anlamlıık boyutunun gerçekleşmesi bakımından olumlu bir etki yaratması beklenebilir. Bunların yanında, psikolojik güçlendirmenin unsurlarından olan etki, bireylerin kendi örgütlerinde bir fark yarattıklarını hissedip hissetmediklerini yansıttığı (Spreitzer vd., 1997) ve buna bağlı olarak, çalışanların eylemlerinin örgütlerinde bir fark yarattığına dair inancının onların adanmışlıklarına katkıda bulunduğu da ifade edilebilir (Stander ve Rothmann, 2010: 6; Jose ve Mampilly, 2014: 97).

Bu bilgiler bağlamında araştırmanın üç numaralı hipotezi şu şekilde oluşturulmuştur:

H3: Psikolojik güçlendirme, çalışanların işe adanmışlıklarını pozitif yönlü ve anlamlı olarak etkilemektedir.

Araştırmanın ilk üç hipotezi, değişkenlerin birbirleri ile olan ikili ilişkilerini sınamaya yöneliktir. Yukarıda bu hipotezlere ilişkin oluşturulan kavramsal çerçeve aynı zamanda aracı değişken rolü sınanan psikolojik güçlendirmenin bağımsız (lider üye etkileşimi) ve bağımlı (işe adanmışlık) değişkenle olan ilişkilerini de ortaya koymaktadır. Değişkenler arasındaki pozitif yönlü ilişkilere dair hipotezler temel alınarak, araştırmanın ana hipotezi şu şekilde oluşturulmuştur:

H4: Lider üye etkileşiminin işe adanmışlık üzerindeki etkisinde psikolojik güçlendirmenin aracılık rolü vardır.

\section{Araştırmanın Yöntemi}

\subsection{Araştırmanın Amacı ve Önemi}

Bu araştırmanın amacı, çalışanların lider üye etkileşimi algılarının işe adanmışlık düzeyleri üzerindeki etkisi ile bu etkide psikolojik güçlendirmenin aracılık rolüne ilişkin varsayımı sınamaktır.

Yapılan yazın taraması sonucunda söz konusu değişkenlerin oluşturulan model temelinde ilişkilendirildiği herhangi bir araştırmaya rastlanmamıştır. Bu nedenle elde edilen sonuçların ve sonuçlara bağlı olarak geliştirilen önerilerin akademik yazına katkı sağlayacağı düşünülmektedir. Araştırmanın ayrıca, lider-üye etkileşiminin ve yönetim tarafından desteklenen psikolojik güçlendirmenin çalışanların işe 
adanmışlıkları üzerindeki etkisini ortaya koyarak, işletme yönetimlerine sahip oldukları insan kaynağını en verimli şekilde değerlendirebilme konusunda rehber olması bakımından önem taşıdığı söylenebilir.

\subsection{Araştırmanın Modeli ve Kullanılan İstatistiksel Yöntemler}

Çalışanların lider üye etkileşimi algılarının işe adanmışlık düzeyleri üzerindeki etkisi ile bu etkide psikolojik güçlendirmenin aracılık rolü olduğu varsayımına ilişkin olarak oluşturulan teorik yapının test edilmesi amacını taşıyan bu araştırmanın modeli Şekil 1'de görülmektedir.

Şekil 1. Araştırmanın Modeli

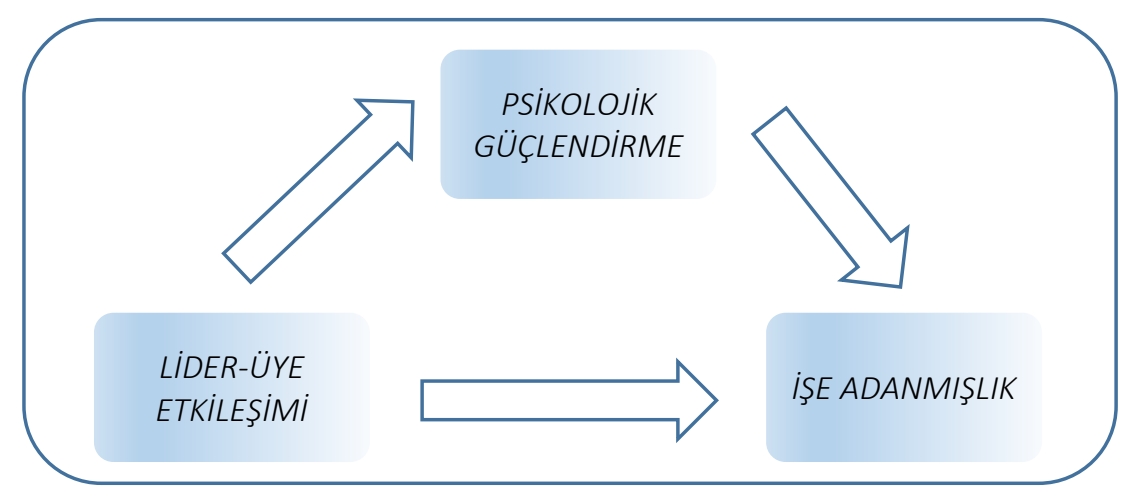

Araştırmada, ölçeklere ilişkin yapısal geçerlilikler açıklayıcı ve doğrulayıcı faktör analizi ile güvenilirlik düzeyleri ise Cronbac'h alpha katsayısı ile değerlendirilmiştir. Araştırma modelinin test edilmesinde Yapısal Eşitlik Modeli kullanılmıştır. Yapılan istatistiki değerlendirmeler sonucu belirlenen tam aracılık etkisinin anlamlı olup olmadığı ise SOBEL testi ile sınanmıştır.

\subsection{Araştırma Evreni ve Örneklem}

Araştırma evrenini Ordu ilinde faaliyet göstermekte olan tekstil işletmeleri çalışanları, araştırma örneklemini ise, bu işletmeler arasından tesadüfi örnekleme yöntemi ile belirlenen üç işletmenin çalışanları oluşturmaktadır. Söz konusu işletmelerde toplam çalışan sayısı 700 olarak tespit edilmiştir. Birey sayısı bilinen araştırma evreni için örneklem büyüklüğü hesaplama yöntemi kullanılarak (Şahin, 2014: 126) gerekli örneklem büyüklüğü 182 olarak hesaplanmıştır. Araştırma verileri hazırlanan anket formları aracılığı ile elde edilmiştir. Bu bağlamda çalışanlara toplam 300 adet anket formu dağıtılmış, bu formlardan 210 adet geri dönüş sağlanmıştır. Ancak katılımcılar tarafından doldurulan anket formlarından 24 tanesi eksik ve hatalı olduğu tespit edildiğinden değerlendirme dışı bırakılmıştır. Sonuç olarak 186 adet anket formu veri setini oluşturmak üzere araştırmaya dâhil edilmiştir.

\subsection{Veri Toplama Araçları}

Lider-Üye Etkileşimi Ölçeği: Araştırmanın bağımsız değişkeni olan lider-üye etkileşimi algısını ölçmek için Liden ve Maslyn (1998) tarafından geliştirilen Lider-Üye Etkileşimi (LMX-12) ölçeği kullanılmıştır. Ölçeğin orijinal formu toplam 12 madde ve 4 boyuttan (etki, katkı, vefakârlık ve profesyonel saygı) oluşmaktadır.

Işe Adanmışlık Ölçeği: Araştırmanın bağımlı değişkeni olan işe adanmışlık düzeyini ölçmek için Schaufeli, Bakker ve Salanova (2006) tarafından geliştirilen Utrecht işe Adanmışlık Ölçeği (UWES-9) kullanılmıştır. Ölçeğin orijinal formu toplam 9 madde ve 3 boyuttan (dinçlik, adanmışlık, yoğunlaşma) oluşmaktadır.

Psikolojik Güçlendirme Ölçeği: Araştırmanın aracı değişkeni olan psikolojik güçlendirme düzeyini ölçmek amacıyla Spreitzer (1995) tarafından geliştirilen Psikolojik Güçlendirme Ölçeği (PEI) kullanılmıştır. Ölçeğin orijinal formu 12 ifade ve 4 boyuttan (anlam, yetkinlik, özerklik ve yetki) oluşmaktadır. 


\section{Bulgular}

Araştırmanın bu bölümünde katılımcıların demografik özelliklerine, kullanılan ölçeklerin yapısal geçerliliklerini belirlemek için yapılan açıklayıcı ve doğrulayıcı faktör analizlerine ve araştırma modelinin sınanması amacıyla oluşturulan yapısal eşitlik modeline ilişkin bulgular yer almaktadır.

\subsection{Araştırma Evrenine İlişkin Bulgular}

Araştırma evrenin ilişkin istatistiki bilgiler Tablo 1'de yer almaktadır.

Tablo 1. Araştırma Evrenine ilişskin Demografik Bilgiler

\begin{tabular}{|c|c|c|c|}
\hline \multirow{4}{*}{ Cinsiyet } & & Frekans & Yüzde (\%) \\
\hline & Kadın & 88 & 47,3 \\
\hline & Erkek & 98 & 52,7 \\
\hline & Toplam & 186 & 100 \\
\hline \multirow{4}{*}{ Medeni Durum } & Evli & 103 & 55,4 \\
\hline & Bekâr & 78 & 41,9 \\
\hline & Diğer & 5 & 2,7 \\
\hline & Toplam & 186 & 100 \\
\hline \multirow{5}{*}{ Yaş } & $16-25$ yaş arası & 52 & 28 \\
\hline & 26-35 yaş arası & 78 & 41,9 \\
\hline & $36-45$ yaş arası & 50 & 26,9 \\
\hline & 46 yaş ve üzeri & 6 & 3,2 \\
\hline & Toplam & 186 & 100 \\
\hline \multirow{4}{*}{ Eğitim Düzeyi } & ilköğretim & 80 & 43 \\
\hline & Lise & 80 & 43 \\
\hline & $\begin{array}{l}\text { Üniversite } \\
\text { (Ön Lisans-Lisans-Lisansüstü) }\end{array}$ & 26 & 14 \\
\hline & Toplam & 186 & 100 \\
\hline \multirow{4}{*}{$\begin{array}{l}\text { Toplam Çalışma } \\
\text { Süresi }\end{array}$} & 5 yıl ve daha az & 126 & 67,7 \\
\hline & 6-10 yıl arası & 48 & 25,8 \\
\hline & 11 yıl ve daha fazla & 12 & 6,5 \\
\hline & Toplam & 186 & 100 \\
\hline
\end{tabular}

Katılımcıların demografik özellikleri incelendiğinde \%47,3'ünün kadın, \%52,7'sinin ise erkek olduğu, \%55,4'ünü evli, \%41,9'unu ise bekâr çalışanların oluşturduğu görülmektedir. Katılımcıların \%41,9'luk kısmı 26-35 yaş arasında yer alırken, 46 yaş üstü çalışanlar \%3,2 ile en az katılımcının bulunduğu yaş grubunu oluşturmaktadır. Ayrıca, araştırma evreninde yer alan çalışanların ilköğretim ve lise mezunu oranlarının eşit olduğu (\%43) ve \%67,7 ile çoğunluğunun toplam iş deneyiminin 5 yıldan az olduğu tespit edilmiştir.

\section{2. Ölçeklere iliş̧in Geçerlilik ve Güvenirlik Bulguları}

$\mathrm{Bu}$ bölümde araştırmada kullanılan ölçeklerin yapısal geçerlilikleri ile güvenirlikleri değerlendirilmiştir. Ölçeklerin yapı geçerliliğini belirlemek için açıklayıcı ve doğrulayıcı faktör analizleri, ölçüm güvenirliğini belirlemek için ise Cronbac'h alpha katsayısı kullanılmıştır.

\subsubsection{Lider Üye Etkileşimi Ölçeği Geçerlilik ve Güvenirlik Bulguları}

Bu ölçeğe ilişkin güvenirlik katsayısı ölçek geneli için 0,92; etki, vefakârlık ve saygı boyutlarının birleşiminden oluşan ilk boyut için 0,92; katkı boyutu için ise 0,88 olarak hesaplanmıştır.

Lider üye etkileşimi ölçeğine ilişkin yapı geçerliliği açıklayıcı ve doğrulayıcı faktör analizi ile saptanmıştır. Açıklayıcı faktör analizi yapmadan önce verilerin uygunluğunu tespit etmek amacıyla Örneklem Yeterliliği Testi (KMO) ve değişkenler arasında ilişki olup olmadığını belirleyen Bartlett's Küresellik Testi yapılmıştır. Elde edilen sonuçlar örneklem büyüklüğünün faktör analizi yapmak için yeterli olduğunu 
göstermektedir ( $\mathrm{KMO}=0,881>0,60)$. Varimax yöntemi ile yapılan açıklayıcı faktör analizi sonucunda ölçek, iki faktörlü bir yapı oluşturmuştur. Oluşan iki faktörlü yapı toplam varyansın 0,67'sini açıklamaktadır. Açıklayıcı faktör analizi sonucu oluşan iki faktörlü yapının elde edilen verilerle uyumlu olup olmadığı 2. Düzey DFA ile değerlendirilmiştir. İkinci düzey doğrulayıcı faktör analizinde değişkenlerin birbirleriyle bağlantısız birden fazla faktör altında toplandığı ve bu faktörlerin de kapsayıcı tek bir faktör altında birleştiği bir model önerilmektedir (Meydan ve Şeşen, 2015: 23). Bu durumda ölçeğin açıklayıcı faktör analizi ile elde edilen iki faktörünün, bir üst yapı olarak tanımlanan lider üye etkileşimi örtük değişkenini temsil ettiği de kanıtlanmaktadır. Sonuç olarak, 2. Düzey doğrulayıcı faktör analizi uyum iyiliği değerleri yapısal geçerliliği doğruladığı, ayrıca oluşturulan araştırma modeli ve araştırma amacına uygun olduğu için ölçeğe ilişkin 2. Düzey doğrulayııı faktör analizi ile elde edilen yapı modele dâhil edilmiştir.

Oluşturulan 2. Düzey DFA ölçüm modeli Şekil 2'de görülmektedir.

Şekil 2. Lider Üye Etkileşimi Ölçeği ỉkinci Düzey Doğrulayıcı Faktör Analizi

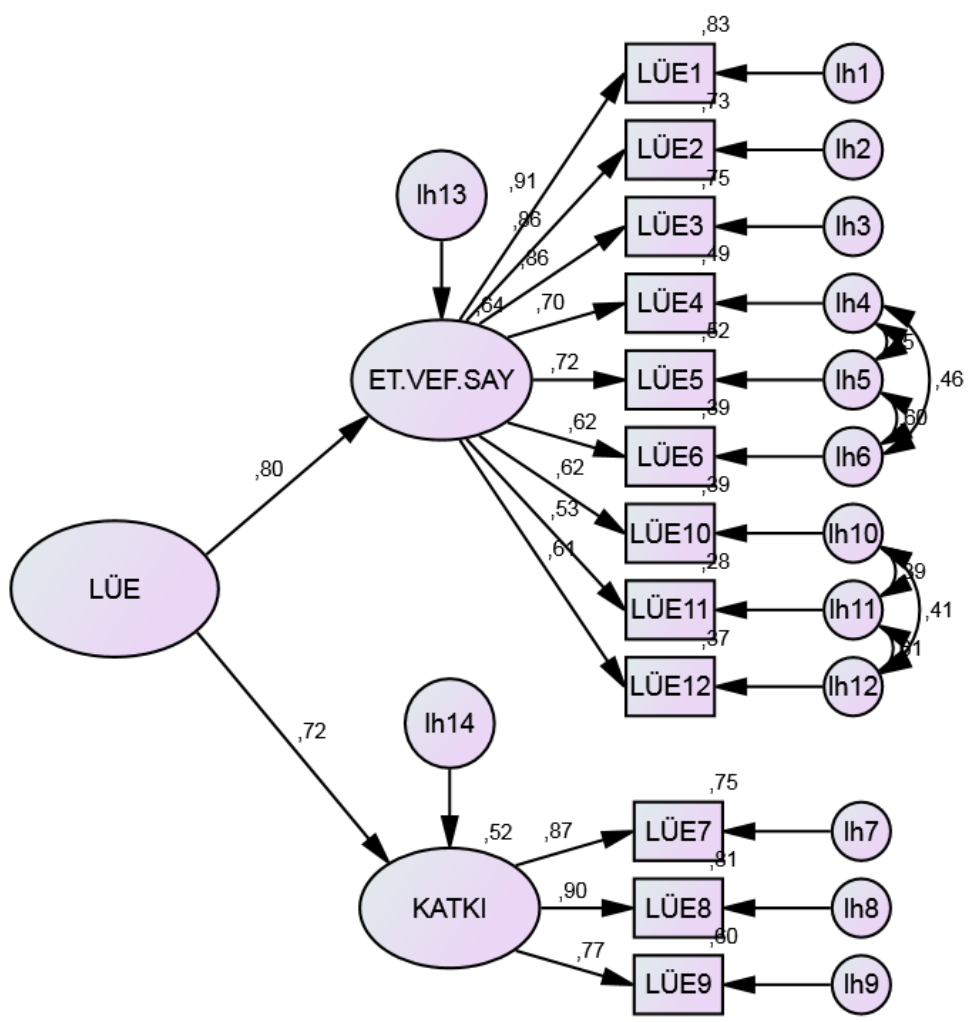

Lider üye etkileşimi ölçeği iki faktörlü yapısını doğrulamak için yapılan 2. Düzey DFA sonucu elde edilen uyum istatistikleri Tablo 2'de verilmiştir. Uyum istatistikleri, oluşan yapının geçerli olduğunu doğrulamaktadır.

Tablo 2. Lider Üye Etkileşimi Ölçeği Doğrulayıcı Faktör Analizi Uyum İyiliği Değerleri

\begin{tabular}{lcccc}
\hline Indeks Adı & \multicolumn{2}{c}{ Eşik Değer } & Ölçek Değeri & Uyum Durumu \\
& ìyi Uyum & Kabul Edilebilir & & \\
\hline $\mathrm{X}^{2} / \mathrm{df}$ & $\leq 3$ & $\leq 4-5$ & 2,197 & İyi Uyum \\
$\mathrm{GFI}$ & $\geq 0,90$ & $\geq 0,89-0,85$ & 0,917 & İyi Uyum \\
$\mathrm{CFI}$ & $\geq 0,95$ & $\geq 0,90$ & 0,965 & İyi Uyum \\
$\mathrm{RMSEA}$ & $\leq 0,05$ & $\leq 0,06-0,08$ & 0,080 & Kabul Edilebilir \\
\hline
\end{tabular}




\subsection{2. İşe Adanmışlık Ölçeği Geçerlilik ve Güvenirlik Bulguları}

İse adanmışlık ölçeği geneline ilişkin güvenirlik katsayısı 0,87 olarak hesaplanmıştır. Ölçekte yer alan yedinci ifade (Yaptığım işle guru duyarım) ölçek güvenirliğini düşürdüğü için ölçekten çıkartılmıştır. Lider üye etkileşimi ölçeğine ilişkin yapı geçerliliği açıklayıcı ve doğrulayıcı faktör analizi ile saptanmıştır. Açıklayıcı faktör analizi yapmadan önce verilerin uygunluğunu tespit etmek amacıyla Örneklem Yeterliliği Testi (KMO) ve değişkenler arasında ilişki olup olmadığını belirleyen Bartlett's Küresellik Testi yapılmıştır. Elde edilen sonuçlar örneklem büyüklüğünün faktör analizi yapmak için yeterli olduğunu göstermektedir $(\mathrm{KMO}=0,823>0,60)$. Varimax yöntemi ile yapılan açıklayıcı faktör analizi sonucunda dokuzuncu ifade (Çalışırken kendimden geçerim) binişik faktör yükü nedeniyle ölçekten çıkartılmıştır. Kalan yedi maddelik şekli ile açıklayıcı faktör analizi tekrar edilmiş ve ölçek tek faktörlü bir yapı meydana getirmiştir. Oluşan tek faktörlü yapı toplam varyansın \%59'unu açıklamaktadır. Açıklayıcı faktör analizi sonucu oluşan tek faktörlü yapının elde edilen verilerle uyumlu olup olmadığı DFA ile belirlenmiştir. Oluşturulan ölçüm modeli Şekil 3'de görülmektedir.

Şekil 3. İşe Adanmışlık Ölçeği Doğrulayıcı Faktör Analizi

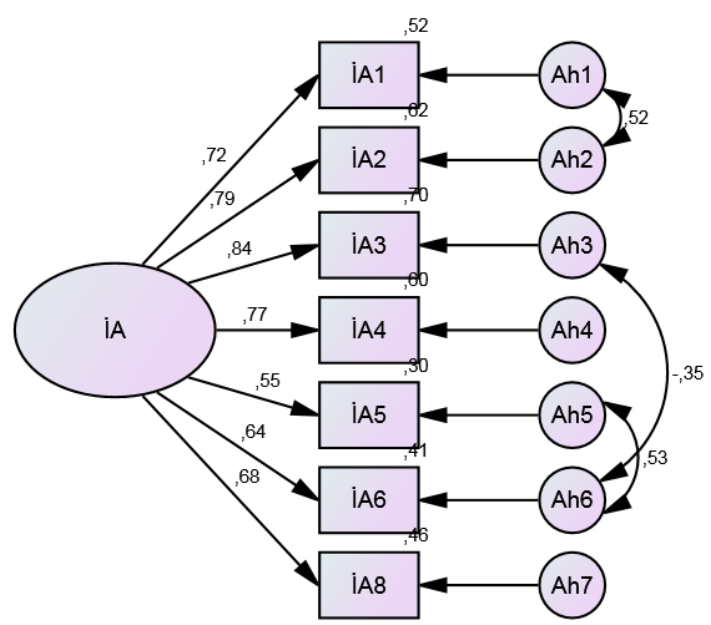

Işe adanmışık ölçeği tek faktörlü yapısını doğrulamak için yapılan DFA sonucu elde edilen uyum istatistikleri Tablo 3'de verilmiştir. Uyum istatistikleri, oluşan yapının geçerli olduğunu doğrulamaktadır.

Tablo 3. İşe Adanmışlık Ölçeği DFA Uyum İyiliği Değerleri

\begin{tabular}{lcccc}
\hline Indeks Adı & iyi Uyum & $\begin{array}{c}\text { Esik Değer } \\
\text { Kabul Edilebilir }\end{array}$ & Ölçek Değeri & Uyum Durumu \\
\hline $\mathrm{X}^{2} / \mathrm{df}$ & $\leq 3$ & $\leq 4-5$ & 1,771 & Iyi Uyum \\
$\mathrm{GFI}$ & $\geq 0,90$ & $\geq 0,89-0,85$ & 0,973 & İyi Uyum \\
$\mathrm{CFI}$ & $\geq 0,95$ & $\geq 0,90$ & 0,988 & İyi Uyum \\
RMSEA & $\leq 0,05$ & $\leq 0,06-0,08$ & 0,065 & Kabul Edilebilir \\
\hline
\end{tabular}

\subsubsection{Psikolojik Güçlendirme Ölçeği Geçerlilik ve Güvenirlik Bulguları}

Bu ölçeğe ilişkin güvenirlik katsayısı ölçek geneli için 0,87; anlam boyutu için 0,91; yetkinlik boyutu için 0,82 ; özerklik boyutu için ise 0,89 olarak hesaplanmıştır. Psikolojik güçlendirme ölçeğine ilişkin yapı geçerliliği açıklayıcı ve doğrulayıcı faktör analizi ile saptanmıştır. Açıklayıcı faktör analizi yapmadan önce verilerin uygunluğunu tespit etmek amacıyla Örneklem Yeterliliği Testi (KMO) ve değişkenler arasında ilişki olup olmadığını belirleyen Bartlett's Küresellik Testi yapılmıştır. Elde edilen sonuçlar örneklem büyüklügünün 
faktör analizi yapmak için yeterli olduğunu göstermektedir ( $K M O=0,834>0,60)$. Varimax yöntemi ile yapılan açıklayıcı faktör analizi sonucunda ölçek üç faktörlü bir yapı oluşturmuştur. Oluşan üç faktörlü yapı toplam varyansın 0,74'ünü açıklamaktadır. Açıklayıcı faktör analizi sonucu oluşan üç faktörlü yapının elde edilen verilerle uyumlu olup olmadığı 2. Düzey DFA ile belirlenmiştir. Bunun için oluşturulan 2. Düzey DFA ölçüm modeli Şekil 4'de görülmektedir.

Şekil 4. Psikolojik Güçlendirme Ölçeği İkinci Düzey Doğrulayıcı Faktör Analizi

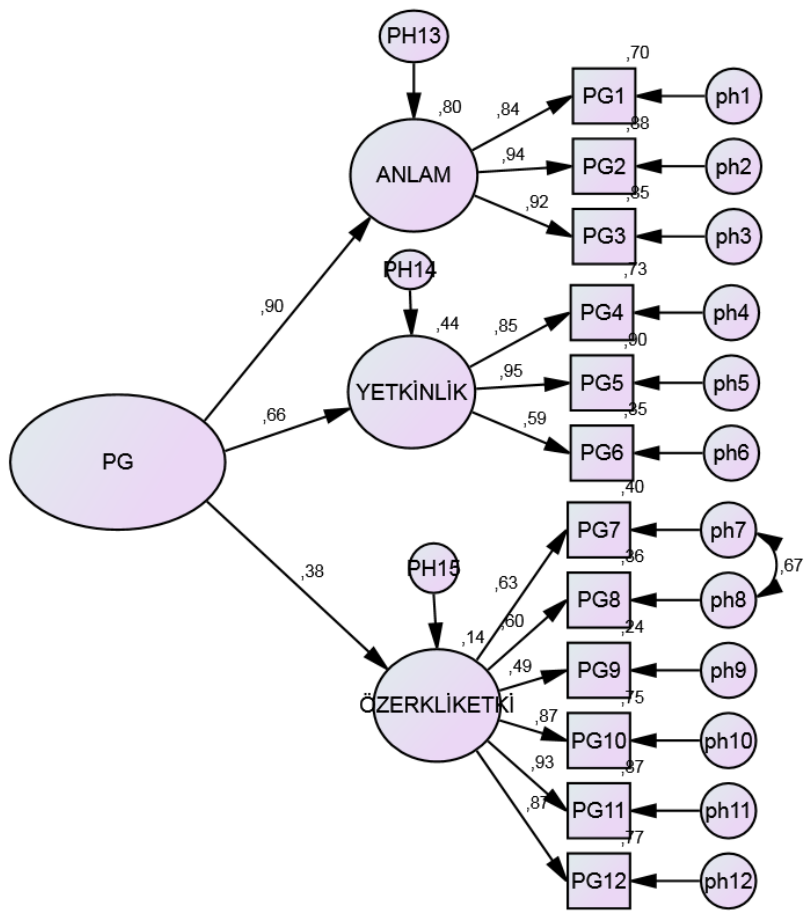

Psikolojik güçlendirme ölçeği üç faktörlü yapısını doğrulamak için yapılan 2. Düzey DFA sonucu elde edilen uyum istatistikleri Tablo 4'de verilmiştir. Uyum istatistikleri, oluşan yapının geçerli olduğunu doğrulamaktadır.

Tablo 4. Psikolojik Güçlendirme Ölçeği DFA Uyum İyiliği Değerleri

\begin{tabular}{lcccc}
\hline Indeks AdI & Iyi Uyum & $\begin{array}{c}\text { Eşik Değer } \\
\text { Kabul Edilebilir }\end{array}$ & Ölçek Değeri & Uyum Durumu \\
\hline $\mathrm{X}^{2} / \mathrm{df}$ & $\leq 3$ & $\leq 4-5$ & 1,904 & İyi Uyum \\
$\mathrm{GFI}$ & $\geq 0,90$ & $\geq 0,89-0,85$ & 0,925 & Iyi Uyum \\
$\mathrm{CFI}$ & $\geq 0,95$ & $\geq 0,90$ & 0,972 & İyi Uyum \\
$\mathrm{RMSEA}$ & $\leq 0,05$ & $\leq 0,06-0,08$ & 0,070 & Kabul Edilebilir \\
\hline
\end{tabular}

\subsection{Araştırma Modelinin YEM ile Sınanmasına İlişkin Bulgular}

Araştırma modelini oluşturan ilişkilerin ve aracılık ilişkisinin test edilmesi için Yapısal Eşitlik Modeli (YEM) kullanılmıştır. Araştırma modelinde görülen lider üye etkileşimi ile işe adanmışlık arasındaki ilişkide psikolojik güçlendirmenin aracı değişken rolü, Baron ve Kenny (1986)'nin geliştirmiş olduğu dört koşuldan oluşan yöntem ile değerlendirilmiştir. Bu yöntemde aracılık etkisinden söz edebilmek için aşă̆ıda belirtilen dört koşulun sağlanması gerekmektedir; 
1. Bağımsız değişkenin (lider üye etkileşimi), bağımlı değişken (işe adanmışlık) üzerinde bir etkisi olmalıdır.

2. Bağımsız değişken (lider üye etkileşimi), aracı değişken (psikolojik güçlendirme) üzerinde etkili olmalıdır.

3. Aracı değişkenin bağımlı değişken üzerinde etkisi olmalıdır.

4. Aracı değişken, ikinci adımdaki regresyon analizine dâhil edildiğinde; bağımsız değişkenle bağımlı değişken arasında anlamlı olmayan ilişki ortaya çıkarsa tam aracılık etkisinden söz edilebilir.

\section{Koşul: Lider üye etkileşimi, çalışanların işe adanmışık düzeylerini etkilemektedir.}

Lider üye etkileşiminin işe adanmışlık üzerindeki etkisini gösteren ve aracılık etkisinin ilk aşamasını oluşturan model Şekil 5'de görülmektedir.

Şekil 5. Aracılık Etkisi Birinci Koşul Yapısal Eşitlik Modeli

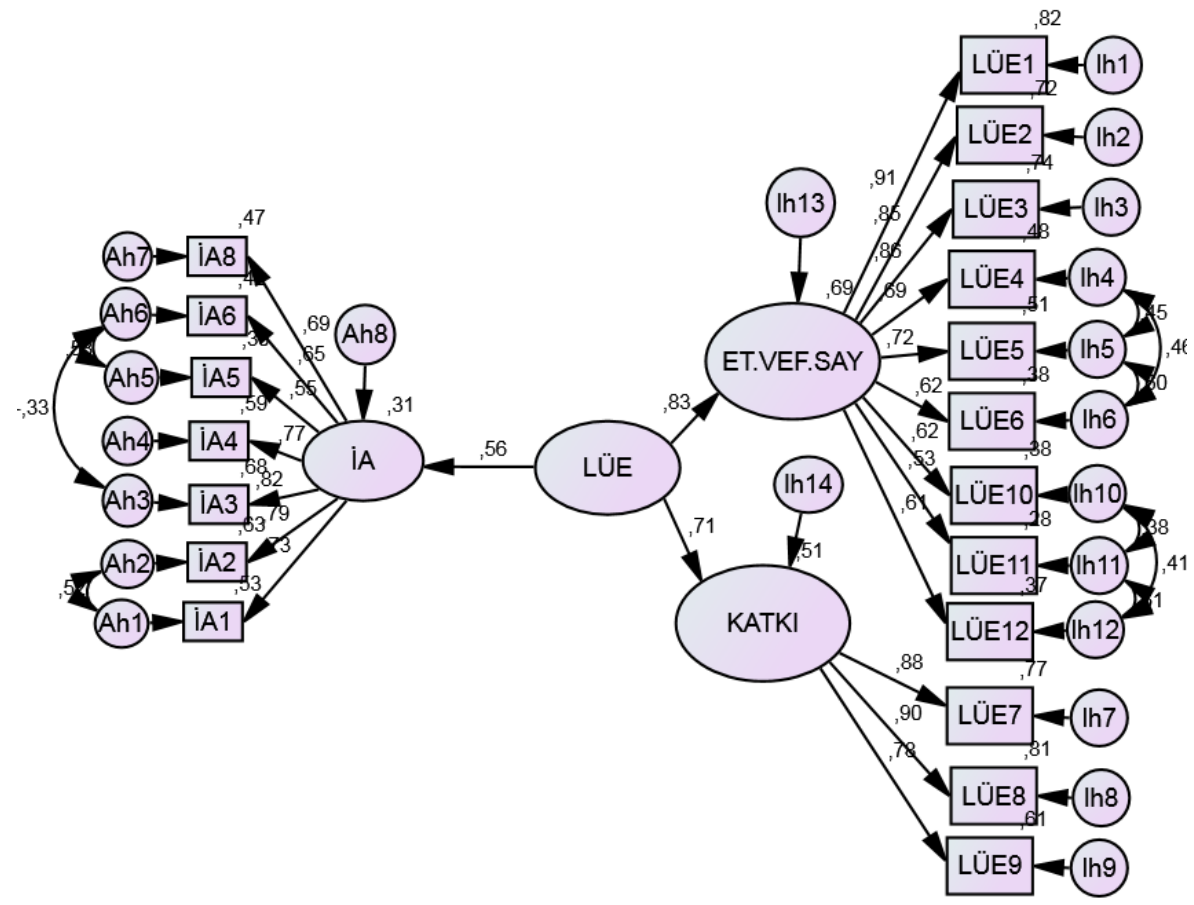

Şekilde görülen modele ilişkin uyum iyiliği değerleri Tablo 5'de yer almaktadır. Değerler, kabul edilebilir ve iyi uyum sınırları içerisinde yer aldığından modelin yapısal olarak uygun oluğu ifade edilebilir.

Tablo 5. Aracılık Etkisi Birinci Koşul Yapısal Eşitlik Modeli Uyum İyiliği Değerleri

\begin{tabular}{lcccc}
\hline Indeks Adı & İyi Uyum & $\begin{array}{c}\text { Eşik Değer } \\
\text { Kabul Edilebilir }\end{array}$ & Ölçek Değeri & Uyum Durumu \\
\hline $\mathrm{X}^{2} / \mathrm{df}$ & $\leq 3$ & $\leq 4-5$ & 1,751 & Iyi Uyum \\
GFI & $\geq 0,90$ & $\geq 0,89-0,85$ & 0,886 & Kabul Edilebilir \\
CFI & $\geq 0,95$ & $\geq 0,90$ & 0,956 & Iyi Uyum \\
RMSEA & $\leq 0,05$ & $\leq 0,06-0,08$ & 0,064 & Kabul Edilebilir \\
\hline
\end{tabular}


Oluşturulan modele göre, değişkenler arasındaki standardize edilmiş $\beta$ katsayıları, standart hata, $p$ değeri ve $R^{2}$ değerleri Tablo $6^{\prime}$ da gösterilmiştir. Tabloda yer alan değerler lider üye etkileşiminin işe adanmışlığı $(\beta=0,56 ; p<0,05)$ etkilediğini, $R^{2}$ değeri ise çalışanların adanmışık davranışlarının \%31'inin lider üye etkileşimi ile açıklanabileceğini ifade etmektedir. Bulgular aynı zamanda araştırmanın bir numaralı hipotezinin ve aracılık testi ilk koşulunun kabul edildiğini de göstermektedir.

Tablo 6: Aracılık Etkisi Birinci Koşula İlişkin Yapısal Eşitlik Modeli Katsayıları

\begin{tabular}{llllll}
\hline Değişkenler & Standardize $\beta$ & Standart Hata & $\mathrm{p}$ & $\mathrm{R}^{2}$ \\
\hline Lider-Üye Etkileşimi & $\rightarrow$ İşe Adanmışlık & 0,56 & 0,089 & $* * *$ & 0,31 \\
\hline
\end{tabular}

\section{Koşul: Lider üye etkileşimi psikolojik güçlendirme düzeyini etkilemektedir.}

Lider üye etkileşiminin psikolojik güçlendirme üzerindeki etkisini gösteren ve aracılık etkisinin ikinci aşamasını oluşturan model Şekil 6 'da görülmektedir.

Şekil 6. Aracılık Etkisi İkinci Koşul Yapısal Eşitlik Modeli

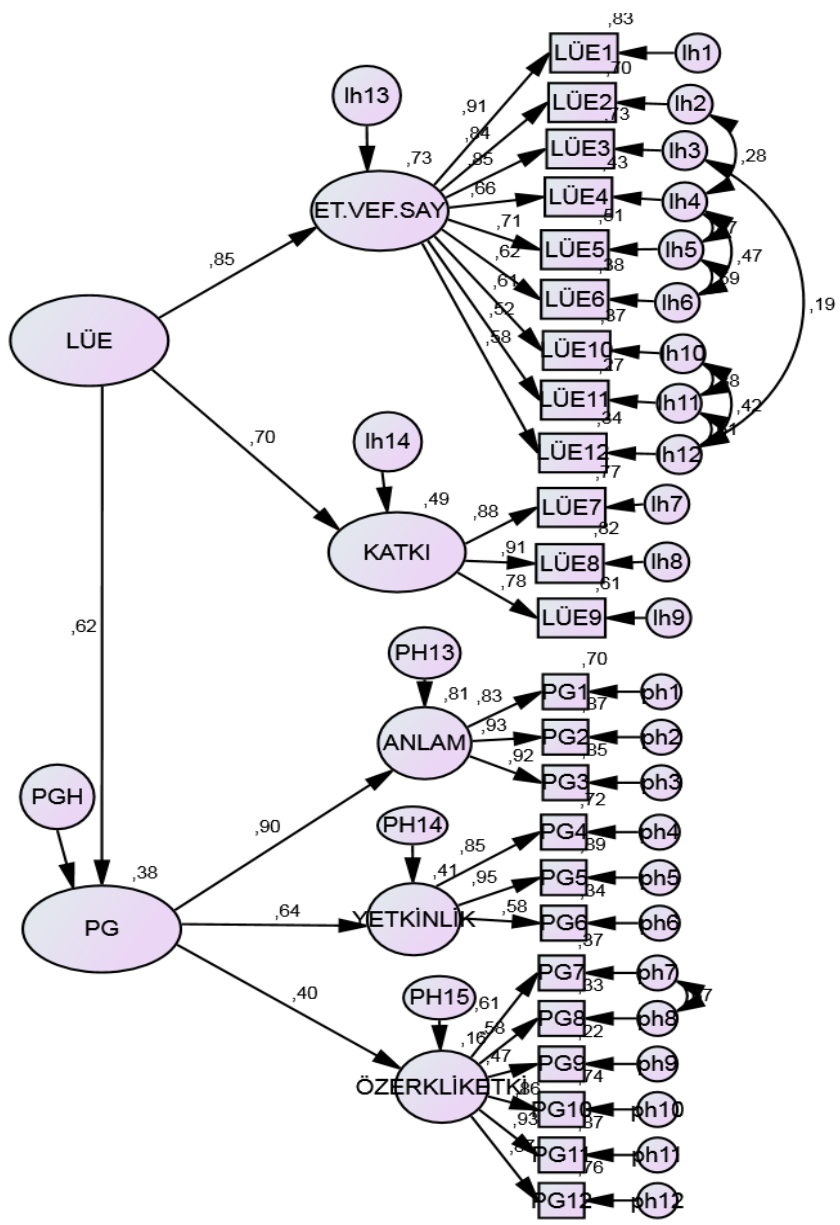

Şekilde görülen modele ilişkin uyum iyiliği değerleri Tablo 7'de yer almaktadır. Tabloda GFI değeri dışındaki tüm değerler, kabul edilebilir ve iyi uyum sınırları içerisinde yer aldığı görülmektedir. GFI değeri ise kabul edilebilir sınırlar içerisinde yer almamaktadır. Ancak, modele ilişkin diğer indeksler kabul edilebilir sınırlar içerisinde yer aldığından ve genel olarak GFI, AGFI ve CFI değerlerinin 0,80 ve 0,90 arasında yer almasının yapının iyi uyuma elverişli oluğunu gösterdiğinden (Arbuckle, 2012) modelin yapısal olarak uygun olduğu ifade edilebilir. 
Lider Üye Etkileşiminin İşe Adanmışıı Üzerindeki Etkisinde Psikolojik Güçlendirmenin Aracı Rolü

Tablo 7. Aracılık Etkisi İkinci Koşul Yapısal Eşitlik Modeli Uyum İyiliği Değerleri

\begin{tabular}{lcccc}
\hline İndeks Adı & \multicolumn{2}{c}{ Eșik Değer } & Ölçek Değeri & Uyum Durumu \\
& İyi Uyum & Kabul Edilebilir & & \\
\hline $\mathrm{X}^{2} / \mathrm{df}$ & $\leq 3$ & $\leq 4-5$ & 1,683 & İyi Uyum \\
$\mathrm{GFI}$ & $\geq 0,90$ & $\geq 0,89-0,85$ & 0,839 & Kabul Edilebilir \\
$\mathrm{CFI}$ & $\geq 0,95$ & $\geq 0,90$ & 0,947 & İyi Uyum \\
RMSEA & $\leq 0,05$ & $\leq 0,06-0,08$ & 0,062 & Kabul Edilebilir \\
\hline
\end{tabular}

Oluşturulan modele göre, değişkenler arasındaki standardize edilmiş $\beta$ katsayıları, standart hata, $p$ değeri ve $R^{2}$ değerleri Tablo $8^{\prime}$ de gösterilmiştir. Tabloda yer alan değerler lider üye etkileşiminin işe adanmışlığı $(\beta=0,64 ; p<0,05)$ etkilediğini $R^{2}$ değeri ise psikolojik güçlendirmenin \%38'inin lider üye etkileşimi ile açıklanabileceğini ifade etmektedir. Bulgular aynı zamanda araştırmanın iki numaralı hipotezinin ve aracılık testi ikinci koşulunun kabul edildiğini de göstermektedir.

Tablo 8. Aracılık Etkisi İkinci Koşula iliş̧kin Yapısal Eşitlik Modeli Katsayıları

\begin{tabular}{lllll}
\hline Değişkenler & Standardize $\beta$ & Standart Hata & $\mathrm{p}$ & $\mathrm{R}^{2}$ \\
\hline Lider üye etkileşimi $\rightarrow$ Psikolojik Güçlendirme & 0,62 & 0,066 & $* * *$ & 0,38 \\
\hline
\end{tabular}

3. Koşul: Lider üye etkileşimi ile işe adanmışlık arasındaki ilişkide psikolojik güçlendirme aracı değişkendir.

Psikolojik güçlendirmenin, lider üye etkileşimi ile işe adanmışık arasındaki aracılık rolünü test etmek amacıyla oluşturulan yapısal eşitlik modeli Şekil 7'de görülmektedir.

Şekil 7. Aracılık Etkisi Yapısal Eşitlik Modeli

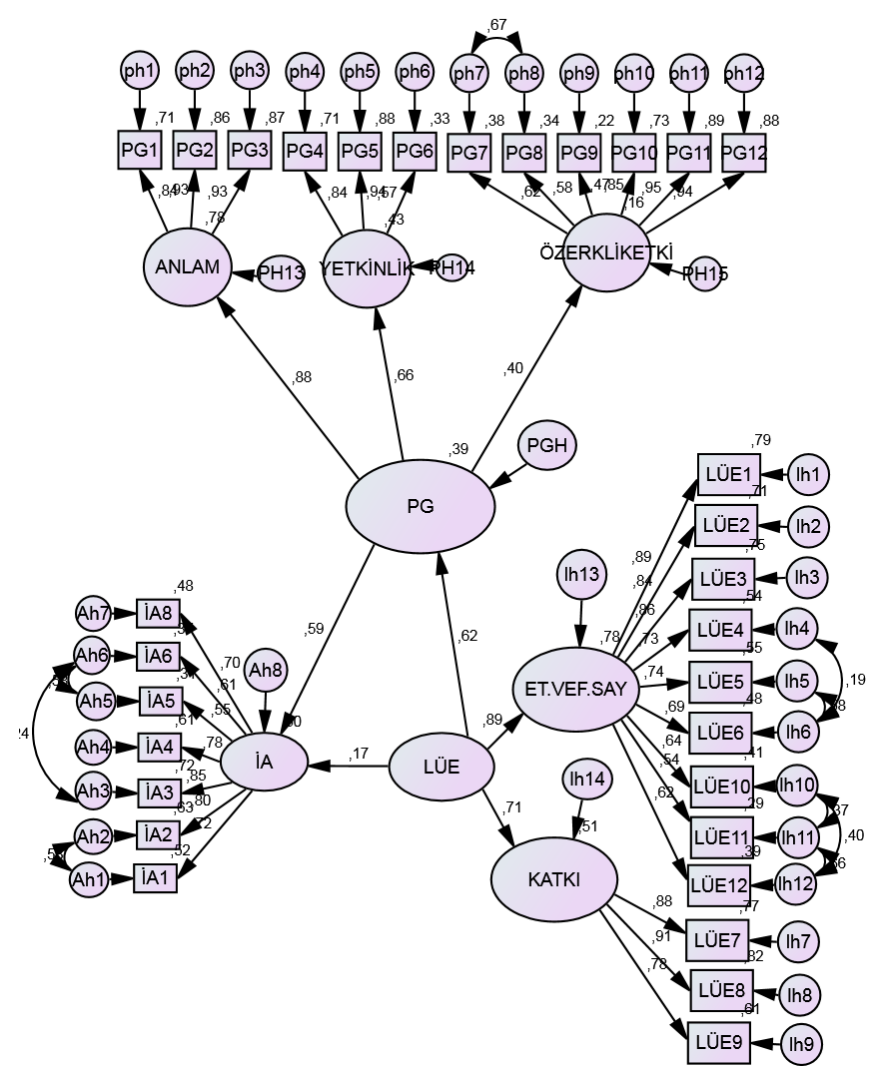


Şekilde görülen modele ilişkin uyum iyiliği değerleri Tablo 9'da yer almaktadır. Değerler, kabul edilebilir ve iyi uyum sınırları içerisinde yer aldığından modelin yapısal olarak uygun oluğu ifade edilebilir. Tablodaki değerler incelendiğinde $X^{2} / d f$ değerinin iyi uyum, CFI ve RMSEA değerlerini kabul edilebilir uyum sınırları içerisinde yer aldığı görülmektedir. GFI değeri ise kabul edilebilir sınırlar içerisinde yer almamaktadır. Ancak, modele ilişkin diğer indeksler kabul edilebilir sınırlar içerisinde yer aldığından ve genel olarak GFI, AGFI ve CFI değerlerinin 0,80 ve 0,90 arasında yer almasının yapının iyi uyuma elverişli oluğunu gösterdiğinden (Arbuckle, 2012) modelin yapısal olarak uygun olduğu ifade edilebilir.

Tablo 9. Aracılık Etkisi Yapısal Eşitlik Modeli Uyum İyiliği Değerleri

\begin{tabular}{|c|c|c|c|c|}
\hline \multirow{2}{*}{ İndeks Adı } & \multicolumn{2}{|c|}{ Eşik Değer } & \multirow{2}{*}{ Ölçek Değeri } & \multirow{2}{*}{ Uyum Durumu } \\
\hline & İyi Uyum & Kabul Edilebilir & & \\
\hline$x^{2} / d f$ & $\leq 3$ & $\leq 4-5$ & 1,673 & İyi Uyum \\
\hline GFI & $\geq 0,90$ & $\geq 0,89-0,85$ & 0,807 & Kabul Edilebilir \\
\hline $\mathrm{CFI}$ & $\geq 0,95$ & $\geq 0,90$ & 0,934 & Kabul Edilebilir \\
\hline RMSEA & $\leq 0,05$ & $\leq 0,06-0,08$ & 0,061 & Kabul Edilebilir \\
\hline
\end{tabular}

Oluşturulan modele göre değişkenler arasındaki standardize edilmiş $\beta$ katsayıları, standart hata, $\mathrm{p}$ ve $\mathrm{R}^{2}$ değerleri Tablo $10^{\prime}$ da görülmektedir.

Tablo 10. Aracılık Etkisi Yapısal Eşitlik Modeli Katsayıları

\begin{tabular}{lllll}
\hline Değişkenler & Standardize $\beta$ & Standart Hata & $\mathrm{p}$ & $\mathrm{R}^{2}$ \\
\hline Lider Üye Etkileşimi $\rightarrow$ Psikolojik Güçlendirme & 0,62 & 0,079 & $* * *$ & 0,38 \\
Lider Üye Etkileşimi $\rightarrow$ İşe Adanmışlık & 0,17 & 0,099 & $\mathbf{0 , 1 3 1}$ & 0,49 \\
Psikolojik Güçlendirme $\rightarrow$ İşe Adanmışlık & 0,59 & 0,388 & $* * *$ & \\
\hline
\end{tabular}

Tablo 10'da görüldüğü gibi aracı değişken modele dâhil edildiğinde, bağımsız değişkenle bağımlı değişken arasındaki ilişkide $p>0,05$ olması, psikolojik güçlendirmenin lider üye etkileşimi ile işe adanmışıı arasındaki ilişkide tam aracılık etkisinin olduğunu göstermektedir. Bu durumda Baron ve Kenny (1986)'nin dördüncü koşulunun da sağlandığı gözlemlenmiştir. Dolayısıyla araştırmanın 3 ve 4 numaralı hipotezleri de desteklenmiştir.

Tam aracılık etkisinin anlamlı olup olmadığı Sobel testi ile değerlendirilmiştir. Sobel testi, değişkenlere ait düzeltilmemiş regresyon katsayıları ( $\beta$ ) ile standart hata değerleri kullanılarak hesaplanmaktadır. Yapılan hesaplamada Z skor katsayısı 1,96'dan büyükse ve anlamlıysa aracılık etkisinin anlamlı olduğu söylenebilir. Araştırma sonuçlarına ilişkin değerler belirtilen koşulları sağladığından $(Z=2,51 ; p=0,011)$ psikolojik güçlendirmenin, lider üye etkileşimi ile işe adanmışlık arasındaki tam aracılık etkisinin anlamlı olduğu ifade edilebilir.

\section{Tartışma ve Sonuç}

Bu çalışma, lider üye etkileşiminin işe adanmışlık üzerindeki etkisini ve psikolojik güçlendirmenin aracılık rolü olup olmadığını belirlemek amacıyla geçekleştirilmiştir. Kavramsal çerçeve ile desteklenerek oluşturulan dört hipotez, istatistiksel analiz yöntemleri ile test edilmiş ve elde edilen bulgular psikolojik güçlendirmenin lider üye etkileşimi ile işe adanmışıı arasındaki ilişkide tam aracılık rolü olduğunu göstermiştir.

Lider üye etkileşiminin çalışanların işe adanmışlıkları üzerinde etkisi olduğu varsayımını ifade eden araştırmanın ilk hipotezi elde edilen bulgular doğrultusunda kabul edilmiştir $(p<0,05)$. Bulgular aynı zamanda, çalışanların işe adanmışlık davranışlarının \%31'inin lider üye etkileşimi ile açıklanabileceğine de işaret etmektedir. Lider üye etkileşimi, diğer liderlik kuramlarından farklı olarak yalnızca liderden izleyiciye 
gerçekleşen tutum, davranış ve uygulamaları değil, izleyicinin lidere olan yaklaşımını da dikkate alan bir bakış açısı içermektedir. Sosyal etkileşim kuramı açısından değerlendirildiğinde, çalışanların lider ile gerçekleştirdikleri etkileşimin karşılığı olarak liderlerine ve işlerine karşı olumlu duygular geliştirdikleri söylenebilir. Buna bağlı olarak iş ile ilgili olumlu duygulara sahip çalışanların ise sahip olduğu tüm bilişsel kapasite ve fiziksel enerji ile işine yoğunlaşması ve kendini işine adamasının daha kolay mümkün olacağı ifade edilebilir. Elde edilen sonuç, yazında yer alan araştırmalar ile de örtüşmektedir. De Oliveira ve Silva (2015), Brezilya'da kâr amacı gütmeyen kuruluşlarda çalışanlar ile yapmış oldukları araştırmada lider üye etkileşimi ile işe adanmışlık arasında pozitif yönlü bir ilişki tespit etmişlerdir. Radstaak ve Hennes (2017), Hollanda'da bir posta ve paketleme şirketi çalışanları ile gerçekleştirdikleri araştırmada, lider üye etkileşiminin çalışanların işe adanmışlıkları üzerindeki etkisini doğrulayacak sonuçlar elde etmişlerdir. Yazarlar, lider üye etkileşiminin getirdiği özerklik ve olumlu geri bildirimlerin çalışanların içsel motivasyonlarını ve dolayısıyla işe adanmışıklarını artırdığını ifade etmektedir. Demir ve Demirkaya (2011), 180 banka çalışanı örnekleminde yapmış oldukları araştırmada, lider üye etkileşiminin örgütsel iletişimi daha sağlıklı hale getirdiğini ve bu iletişim aracılığı ile çalışan adanmışlığını arttırdığını ortaya koymuşlardır.

Lider üye etkileşiminin psikolojik güçlendirmeyi etkilediği varsayımını ifade eden araştırmanın ikinci hipotezi, elde edilen bulgular doğrultusunda kabul edilmiştir $(p<0,05)$. Hipoteze ilişkin bulgular, psikolojik güçlendirmenin \%38'inin lider üye etkileşimi ile açıklanabileceğini de göstermektedir. Psikolojik güçlendirme, liderin sahip olduğu güç ve yetkinin bir kısmını astları ile paylaşmasını da içeren bir süreçtir. Liderin yetkilerini paylaşması ise karşııılı etkileşimin sonucunda ortaya çıkan güven duygusu ile gerçekleşebilmektedir. Bir başka ifadeyle, liderin astlarına olan güveni, onların işleri ile ilgili kararları almalarına ve alınan kararlara daha fazla katılmalarına izin vermesiyle sonuçlanır (Hill, Kang ve Seo, 2014: 774). Bu da, güçlü bir lider üye etkileşiminin çalışanların psikolojik olarak güçlendirilmesi üzerindeki olumlu etkisini açıklayabilir. Elde edilen bulgular, yazında yer alan birçok çalışma ile uyum göstermektedir. Örneğin, Kim ve George (2005), 176 restoran çalışanı ile; Gomez ve Rosen (2001), 13 farklı şirketten 256 çalışan ile; Ceylan vd (2005) ise hizmet sektöründe 111 çalışan ile yaptıkları araştırmalarda lider üye etkileşimi ile çalışanların psikolojik olarak güçlendirmesi üzerindeki pozitif etkinin varlığını doğrulayan bulgular elde etmişlerdir. Yazarlar, lider üye etkileşiminin psikolojik güçlendirme üzerindeki etkisini lider ile izleyici arasında oluşan güven duygusu ile açıklamaktadır.

Araştırmada ayrıca, psikolojik güçlendirmenin işe adanmışlık üzerindeki etkisini ifade eden 3 numaralı hipotez de elde edilen bulgular doğrultusunda kabul edilmiştir. Yapılan araştırmalar, psikolojik güçlendirmenin, özellikle içermiş olduğu yetki devri ve özerklik unsurları ile çalışanların motivasyonlarını ve öz yeterlilik duygularını arttırdığını ortaya koymaktadır (Meyerson ve Kline, 2008: 446; Jose ve Mampilly, 2014:96; Abdulrab vd., 2017: 1159). Bir başka ifadeyle, psikolojik olarak güçlendirilmiş çalışanın, işi ile ilgili kararları verebilme, kendi özerk alanına sahip olma gibi kazanımlar dolayısıyla işine daha fazla adanmış olacağı söylenebilir.

Lider üye etkileşiminin adanmışlık üzerindeki etkisinde psikolojik güçlendirmenin aracılık rolü olduğu şeklindeki araştırmanın temel hipotezi, elde edilen bulgular doğrultusunda kabul edilmiştir. Bir başka ifadeyle, psikolojik güçlendirmenin, lider üye etkileşiminin çalışanların işe adanmışlıkları üzerindeki etkisinde tam aracıık rolü olduğu doğrulanmıştır. Araştırma bulguları ile doğrulanan tam aracılık rolü, lider üye etkileşiminin işe adanmışlık üzerindeki etkisini, çalışanları psikolojik açıdan güçlendirerek gerçekleştirdiğini göstermektedir. Bu durum, sağlıklı bir şekilde gerçekleşen lider üye etkileşimi sayesinde psikolojik olarak güçlendirilmiş çalışanların işlerine ilişkin adanmışlık duygularının arttığı şeklinde yorumlanabilir. Lider üye etkileşimi yaklaşımında liderler, çalışanları ile kaliteli etkileşimin getirdiği güven duygusuna sahiptirler. Oluşan güven duygusunun, sahip oldukları yetki ve ayrıcalıkların bir bölümünü astlarına devrederek onları güçlendirme tutumu sergilemeleri konusunda liderleri teşvik ettiği söylenebilir. Liderleri tarafından kendilerine yetki devredilen çalışanların ise psikolojik güçlendirmenin kazandırmış olduğu özerklik ve öz yeterlilik duygularının (Bandura, 1994: 71; Spreitzer, 2007: 3-4; Hill, Kang ve Seo, 2014: 774) etkisi ile işleri hakkında olumlu duygular geliştirmesi ve bu bağlamda işe adanmışlıklarının artması mümkün görülmektedir. İşe adanmış çalışanların örgütsel çıktılara olumlu etkisi dikkate alındığında, liderlerin astlarını psikolojik açıdan güçlendirmelerinin önemi ortaya çıkmaktadır. 
Elde edilen sonuçlar, araştırmanın içerdiği sınırlılıklar çerçevesine değerlendirilmelidir. Öncelikle sonuçlar, araştırmanın gerçekleştirildiği örneklem ile sınırlıdır. Araştırmanın örneklemini Ordu ilinde faaliyet gösteren tekstil işletmeleri içerisinden tesadüfi örnekleme yöntemi ile belirlenen üç işletmenin çalışanları oluşturmaktadır. Araştırma sonuçlarının genellenebilirliği açısından farklı sektör ve örneklemlerde tekrarlanmasının doğru bir yaklaşım olacağı değerlendirilebilir. Ayrıca araştırma kesitsel nitelik taşımaktadır. Kesitsel araştırmalarda veriler, tek seferde toplandığından katılımcıların yalnızca o anki duygu ve düşüncelerini yansıtmaktadır. Bu nedenle değişkenler arası ilişkilerin boylamsal araştırmalar ile de test edilmesi önerilebilir.

\section{Kaynaklar}

Abdulrab, M., Zumrah, A. R., Almaamari, Q., \& Altahitah, A. (2017). The role of psychological empowerment on work engagement: The development of conceptual framework. International Journal of Business Management and Economic Research, 8(6), 1157-1163.

Akkaya, T. (2015). Lider-üye etkileşiminin iş doyumuna etkisinde örgütsel iklimin rolü: Hizmet sektöründe bir lojistik şirket uygulaması. Haliç Üniversitesi Sosyal Bilimler Enstitüsü, Yayımlanmamış Doktora Tezi, İstanbul.

Arbuckle, J. L. (2012). IBM SPSS Amos 19 User's Guide. www.amosdevelopment.com/download/ amos.pdf. (Erişim tarihi, 03 Eylül 2018).

Aslam, S. (2017). Psychological empowerment on creativity among employees of IT sector: The mediating role of creative process engagement and intrinsic motivation. Canadian Social Science, 13(6), 11-34.

Bakker, A. B., \& Demerouti, E. (2008). Towards a model of work engagement. Career Development International, 13(3), 209-223.

Bakker, A., Albrecht, S. L., \& Leiter, M.P. (2011). Key questions regarding work engagement. European Journal of Work and Organizational Psychology, 20(1),4-28.

Bal, P. M., \& De Lange, A. H. (2015). From flexibility human resource management to employee engagement and perceived job performance across the lifespan: A multisample study. Journal of Occupational and Organizational Psychology, 88, 126-154.

Babcock-Roberson, M. E., \& Strickland, O. J. (2010). The relationship between charismatic leadership, work engagement and organizational citizenship behaviors. The Journal of Psychology, 144(3), 313-326.

Bağcı, Z. (2013). Çalışanların örgütsel adalet algılarının örgütsel bağlılıkları üzerindeki etkisi: Tekstil sektöründe bir inceleme. Ulus/ararası Yönetim Iktisat ve Işsletme Dergisi, 9(19), 163-184.

Bandura, A. (1994). Self-efficacy. In V. S. Ramachaudran (Ed.), Encyclopedia of Human Behavior. 4, 71-81.

Baron, R. M., \& Kenny, D. A. (1986). The moderator-mediator variable distinction in social psychological research: Conceptual, strategic and statistical considerations. Journal of Personality and Social Psychology, 51(6), 11731182.

Bedük, A., \& Ertürk, E. (2015). Sosyal mübadele teorisi bağlamında güç mesafesi ve örgütsel adalet algılamalarının örgütsel vatandaşlık davranışı üzerindeki etkisi: Bir araştırma. İ̧̧letme Bilimi Dergisi, 3(1), 1-19.

Bernerth, J. B., Armenakis, A. A., Feild, H. S., Giles, W. F., \&Walker, J. H. (2007). Leader-member social exchange (LMSX): Development and validation of a scale. Journal of Organizational Behavior, 28(8), 979-1003.

Blau, P. M. (1964). Exchange and power in social life. New York: Wiley.

Breevaart, K., Bakker, A. B., Demerouti, E., \& Den Heuvel, M. (2015). Leader-member exchange,

work engagement and job performance. Journal of Managerial Psychology, 30(7), 754-770.

Bulgurcu Gürel, E. (2016). Lider-üye etkileşiminin çalışanların tutumları üzerindeki etkisi: Ampirik bir araştırma. Uluslararası Sosyal Araştırmalar Dergisi, 9(43), 1735-1743.

Ceylan, A., Özbal, S., Dinç, A., \& Kesgin, M. (2005). Lider-üye etkileşimi ve güvenin psikolojik güçlendirmeye etkileri üzerine bir araştırma. İstanbul Üniversitesi Iş̧letme Fakültesi Işsletme Iktisadı Enstitüsü Dergisi, 50, 25-40.

Conger, J. A., \& Kanungo, R. N. (1988). The empowerment process: Integrating theory and practice. Academy of Management Review, 13(3), 471-482. 
Çöl, G. (2004). Güçlendirme ve örgütsel bağlılık ilişkisi üzerine bir araştırma. Gebze Yüksek Teknoloji Enstitüsü Sosyal Bilimler Enstitüsü, Yayımlanmamış Doktora Tezi, Gebze.

Dansereau, F., Cashman, J., \& Graen, G. (1973) Instrument- ality theory and equity theory as complementary approaches in predicting the relationship of leadership and turnover Human Performance, 10, 184-200

Dansereau, F., Graen, G. B., \& Haga, W. J. (1975). A vertical dyad linkage approach to leadership within formal organizations. Organizational Behavior and Human Performance, 13(1), 46-78.

De Oliveira, L.B., \& Da Silva, F. R. A. (2015). The effects of high performance work systems and leader-member exchange quality on employee engagement: Evidence from a Brazilian non-profit organization. Procedia Computer Science, $55,1023-1030$

Demir, H., \& Demirkaya, H. (2011). Örgüt kültürü ve lider- üye etkileşiminin adanmışlık ve işten ayrılma niyeti üzerindeki rolü. 19. Yönetim ve Organizasyon Kongresi Bildiriler Kitabı, 421-425.

Dienesch, R. M., \& Liden, R. C., (1986). Leader-Member exchange model of leadership: A critique and further development. Academy of Management Review, 11(3), 618-634.

Dunegan, K.J., Duchon, D., \& Uhl-Bien, M. (1992). Examiningthe link between leader-member exchange and subordinate performance: The role of task analyzability and variety as moderators. Journal of Management, 18(1), 59- 76.

Durmaz, C. (2012). Etkileşimci ve dönüşümcü liderliğin psikolojik güçlendirme algısına etkisinde strese bağlı kişiliğin düzenleyici rolü. Hacettepe Üniversitesi Sosyal Bilimler Enstitüsü, Yayımlanmamış Doktora Tezi, Ankara.

Erdil, O., Keskin, H., İmamoğlu, S. Z., \& Erat, E. (2004). Yönetim tarzı ve çalışma koşulları, arkadaşlık ortamı ve takdir edilme duygusu ile iş tatmini arasındaki ilişkiler: Tekstil sektöründe bir uygulama. Doğuş Üniversitesi Dergisi, 5(1), 17-26.

Erstad, M. (1997). Empowerment and organizational change. International Journal of Contemporary Hospitality Management, 9(73), 325-333.

Gomez, C., \& Rosen, B. (2001). The Leader-member exchange as a link between managerial trust and employee empowerment. Group \& Organization Management, 26(1), 53-69.

Gorgievski, M. J., Bakker, A. B., \& Schaufeli, W.B. (2010). Work engagement and workaholism: Comparing the selfemployed and salaried employees. The Journal of Positive Psychology, 5(1), 83-96.

Graen, G., \& Schielmann, W. (1978). Leader-member agreement: A vertical dyad linkage approach. Journal of Applied Psychology, 63(2), 206-212.

Graen, G. B., \& Uhl-Bien, M. (1991). The transformation of professionals into selfmanaging and partially self-designing contributors: Toward a theory of leadership-making. Management Department Faculty Publications, 1(1), 25-39.

Graen, G. B., \& Uhl-Bien, M. (1995). Relationship-based approach to leadership: Development of leader-member exchange (LMX) theory of leadership over 25 years: Applying a multi-level multi-domain perspective. Leadership Quarterly, 6(2), 219-247.

Gutermann, D., Lehmann-Willenbrock, N., Boer, D., Born, M., \& Voelpel, S. C. (2017). How leaders affect followers' work engagement and performance: Integrating leader-member exchange and crossover theory. British Journal of Management, 28, 299-314.

Gündüz Çekmecelioğlu, H., \& Ülker, F. (2014). Lider - üye etkileşimi ve çalışan tutumları üzerindeki etkisi: Eğitim sektöründe bir araştırma. Kocaeli Üniversitesi Sosyal Bilimler Dergisi, 28, 35-38.

Harter, K., Scmhidt, F. L., \& Hayes, T.L. (2002). Business-unit-level relationship between employee satisfaction, employee engagement, and business outcomes: A meta-analysis. Journal of Applied Psychology, 87(2), 268-279.

Hill, S. N., Kang, J. H. \& Seo, M. G. (2014). The interactive effect of leader-member exchange and electronic communication on employee psychological empowerment and work outcomes. The Leadership Quarterly, 25, 772-783.

Jose, G., \& Mampilly, S.R. (2014). Psychological empowerment as a predictor of employee engagement: An empirical attestation. Global Business Review, 15(1), 93-104

Kahn, R. L., Wolfe, D. M., Quinn, R. P., Snoek, J. D., \& Rosenthal, R. A. (1964). Organizational stress: Studies in role conflict and ambiguity. New York: Wiley.

Kahn, W. A. (1990). Psychological conditions of personal engagement and disengagement at work. Academy of Management Journal, 33(4), 692-724.

Katz, D., \& Kahn, R. L. (1978). The social psychology of organizations. (2nd Ed.). New York: Wiley. 
Kesen, M. (2015). Psikolojik güçlendirme çalışanların sosyal kaytarma davranışlarını azaltır mı? Journal of Yasar University, 10(38), 6478-6554.

Kim, B. P., \& George, R. T (2005). The relationship between leader-member exchange (LMX) and psychological empowerment: A quick casual restaurant employee correlation study. Journal of Hospitality \& Tourism Research, 29 (4), 468-483.

Liden, R. C., \& Maslyn, J. M. (1998). Multidimensionality of leader-member exchange: An empirical assessment through scale development. Journal of Management, 24(1), 43-72.

Macey, W. H., \& Schneider, B. (2008). The meaning of employee engagement. Industrial and Organizational Psychology, $1(1), 3-30$.

Mahmood, A., \& Sahar, A. (2017). Impact of psychological empowerment and perceived career support on employee work engagement with the mediating role of affective commitment. Pakistan Journal of Commerce and Social Sciences, 11(3), 1084-1099.

Maus, A. L. (2018). Employee engagement and leader member exchange: A comparative study of for-profit university staff members. University of Phoenix.

Matta, F. K., Scott, B. A., Koopman, J., \& Conlon, D. E. (2015). Does seeing "eye to eye" affect work engagement and organizational citizenship behavior? A role theory perspective on LMX agreement. Academy of Management Journal, 58 (6), 1686-1708.

May, D. R., Gilson, R. L. \& Harter, L. M. (2004). The psychological conditions of meaningfulness, safety and availability and the engagement of the human spirit at work. Journal of Occupational and Organizational Psychology, 77(1), 11-37.

Meng, F., \& Wu, J. (2015). Merit pay fairness, leader-member exchange, and job engagement: Evidence from mainland China. Review of Public Personnel Administration, 35(1), 47-69.

Meydan, C., \& Şeşen, H. (2015). Yapısal eşitlik modellemesi AMOS uygulamaları. Detay Yayıncılık: Ankara.

Meyerson, S. L., \& Kline, T. J. B. (2008). Psychological and environmental empowerment: Antecedents and consequences. Leadership \& Organization Development Journal, 29(5), 444-460.

Özutku, H., Ağca, V., \& Cevrioğlu, E. (2008). Lider-üye etkileşim teorisi çerçevesinde, yönetici-ast etkileşimi ile örgütsel bağıııı boyutları ve iş performansı arasındaki ilişki: Ampirik bir inceleme. Atatürk Üniversitesi Iktisadi ve Idari Bilimler Dergisi, 22(2),193-210.

Pastor, J. (1996). Empowerment: What it is and what it is not. Empowerment in Organizations, 4(2), 5-7.

Radstaak, M., \& Hennes, A. (2017). Leader-member exchange fosters work engagement: The mediating role of job crafting. SA Journal of Industrial Psychology, 43(1), 1-11.

Robertson-Smith, G., \& Markwick, C. (2009). Employee engagement a review of current thinking. Institute for Employment Studies. UK.

Saks, A. M. (2006). Antecedents and consequences of employee engagement. Journal of Managerial Psychology, 21(7), 600-617.

Salanova, M., \& Schaufeli, W. B. (2008). A cross-national study of work engagement as a mediator between job resources and proactive behavior. International Journal of Human Resource Management, 19, 116-131.

Salazar, J., Pfaffenger, C., \& Salazar, L. (2006). Locus of control vs. employee empowerment and the relationship with hotel managers' job satisfaction. Journal of Human Resources in Hospitality\&Tourism, 5(1), 1-15.

Schaufeli, W. B., Salanova, M., Gonzalez-Roma, V., \& Bakker, A. B. (2002). The measurement of engagement and burnout: A two sample confirmatory factor analytic approach. Journal of Happiness Studies, 3(1), 71-92.

Schaufeli, W. B. \& Bakker, A. B. (2004). Job demands, job resources, and their relationship with burnout and engagement: A multi-sample study. Journal of Organizational Behavior, 25(3), 293-315.

Schaufeli, W. B., Bakker, A. B., \& Salanova, M. (2006). The measurement of work engagement with a short questionnaire, a cross-national study. Educational and Psychological Measurement, 66(4), 701-716.

Schaufeli, W. B., \& Bakker, A. B. (2010). Defining and measuring work engagement: Bringing clarity to the concept. In A. B. Bakker and M. P. Leiter (eds), Work Engagement - A Handbook of Essential Theory and Research, New York: Psychology Press.

Schermuly, C. C., \& Meyer, B. (2016). Good relationships at work: The effects of leader -member exchange and teammember exchange on psychological empowerment, emotional exhaustion, and depression. Journal of Organizational Behavior, 37, 673-691. 
Sekhar, C., Patwardhan, M., \& Vyas, V. (2018). Linking work engagement to job performance through flexible human resource management. Advances in Developing Human Resources, 20(1), 72-87.

Sonnentag, S., Mojza, E. J., Binnewies, C., \& Scholl, A. (2008). Being engaged at work and detached at home: A weeklevel study on work engagement, psychological detachment and affect. In: Work \& Stress, 22(3),257-276.

Spreitzer, G. M. (1995). Psychological empowerment in the workplace: Dimensions, measurement and validation. Academy of Management Journal, 38(5), 1442-1465.

Spreitzer, G. M., Kzilos, M. A. ve Nason, S. W. (1997). A dimensional analysis of the relationship between psychological empowerment and effectiveness, satisfaction, and strain. Journal of Management, 23 (5), 679- 704.

Spreitzer, G. M. (2007). Taking Stock: A review of more than twenty years of research on empowerment at work. Cary Cooper and Julian Barling (Ed), Handbook of Organizational Behavior (54-73). Thousand Oaks, CA: Sage.

Şahin, B. (2014). Metodoloji. Abdurrahman Tanrıöğren (Ed), Bilimsel Araştırma Yöntemleri (111-130). Ankara: Anı Yayıncılık.

Stander, M. W., \& Rothmann, S. (2010). Psychological empowerment, job insecurity and employee engagement. SA Journal of Industrial Psychology, 36(1), 1-8.

Şan, B. Ç. (2017). Öğretmenlerin ve okul yöneticilerinin psikolojik güçlendirme ve örgütsel bağlılıklarına ilişkin algıları. Pamukkale Üniversitesi Eğitim Bilimleri Enstitüsü, Yayımlanmamış Yüksek Lisans Tezi, Denizli.

Thomas, K. W., \& Velthouse, B. A. (1990). Cognitive elements of empowerment: An interpretive model of intrinsic task motivation. Academy of Management Review, 15(4), 666-681.

Walker, M. J. (2011). Trust factors and the leader-member exchange relationship in diverse organizations: A quantitative study. Capella University, Doctoral dissertation.

Wayne, S. J., \& Green, S. A. (1993). The effects of leader-member exchange on employee citizenship and impression management behavior. Human Relations, 46(12), 1431-1440. 